経営史 学

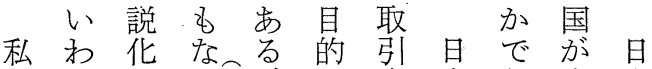
はゆさい1がを高本あ帝本 かる下年財一向率資る 国近 てかい閥方七資主海史 宮の る 商 体同さ学 本道業質 時れ独究 又唯な資なた占の 次上本い日。度立 教わの乙本従な場 授少性 そ, の来ど か をつ格の財の文ら 中た解歴閥こらな 心日明史のの、さ 之本に的体上財れ すの寄特質ら閥た る資与性をなの財 鴻本す の 解研日閥 池制る 解 明究本研 研成し、明究視経究 究立、史ま方角済は ルのた光配拉 1 重生れる然の物 プ要産自の必進主 そな者体、要行秝 面階は閥あ強財 にを級資のり調閥 市分本内、諸 鴻き华主部現 諸業 家加通制造の財吕 ににし度攵財閥各 つすてを研閥に産 いる産生究再よ業 てこ業み文編る 分 こと資だ、成国野 のに本す必期家に 問な家条要に・物 題る階件灾特社い をだ級をあい会て 考 万肪古ての占 察了生っこ支め 乞。季てと配た た机いはのを生 こるない有批産

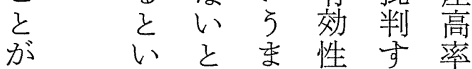
あ ら、定灾性方率含連

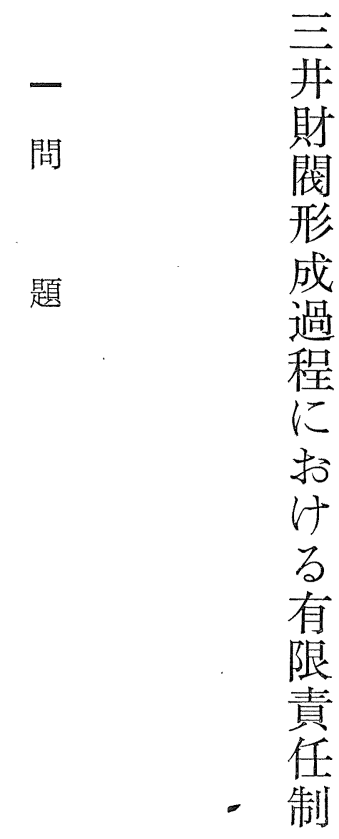


つはと閥す会全て的し所場幣䄈っ ○の、同形玉社な有な、有に主々にた

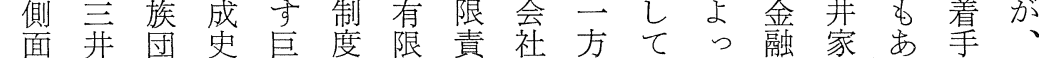
柴を財の研大学責任制、、て 政はるし 現 垣安閥観究化、任制度三心、策、5 和き形点のし支制をで井よ三学旧といは 夫ら成吕重つ配を採 あ合い并担幕考

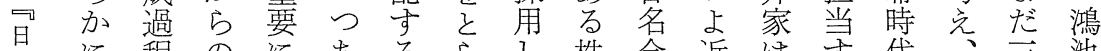
本に程のにあるらら株会近 金しに研しっ諸せた式社代政るに中年研

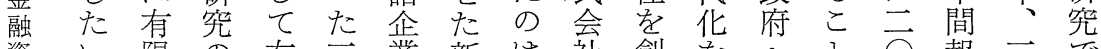

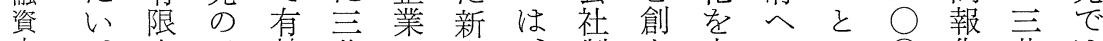
本。責必效井に商、制立志のに○告井は 分任要な家採法ここ度し 向依よ年的研十

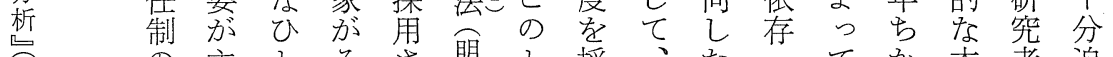

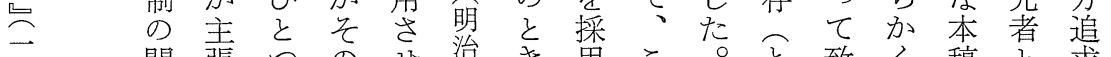
九間張つの せ治き用こ文致く稿と求 六 五 年、

東

京

大

出

版

会

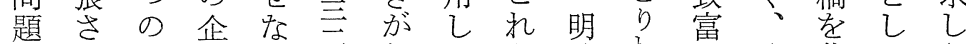
は和方業村年初たら治为し公草て党 いて 法群れ六め財株四官た金しはな かいでにば月で閥式三宔の為た素か にる3岛全、二あコ会年金で替次人口 処くる 社安六つン社二报、学第のた

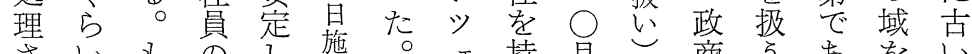
さいるの の 施。

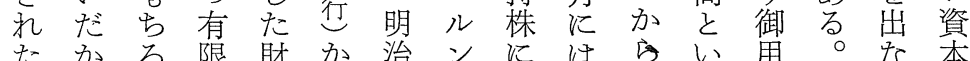
たから限財か治ンにはらい用。な本

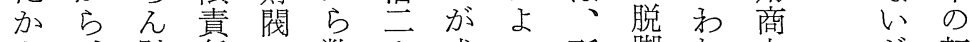

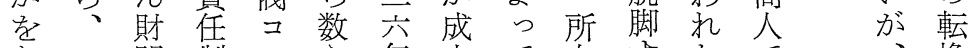
あこ閥制ン党年立て 有卞たで、換

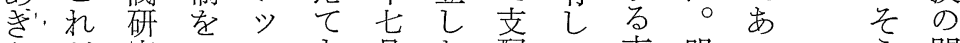

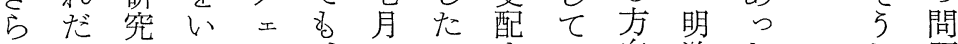
汀江ル、のの专い向治た題

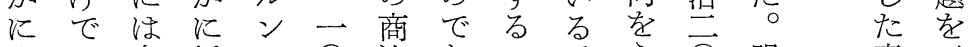

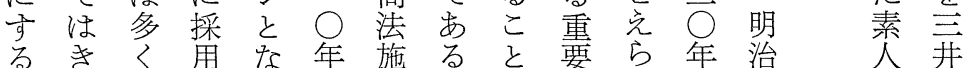
るきく用な年施ると要ら年治合茾

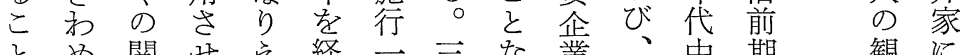

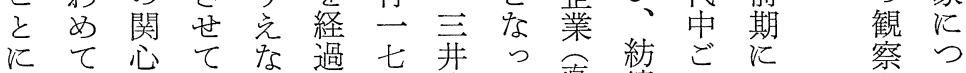

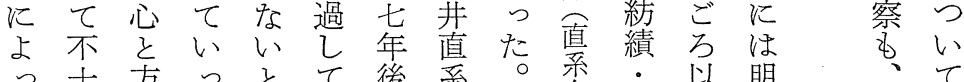
て十方法たいて後系。系会製降治 閣研 て分法た い方尔

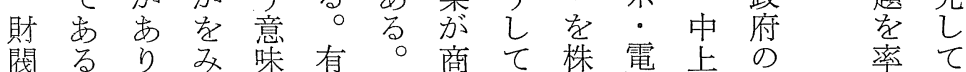

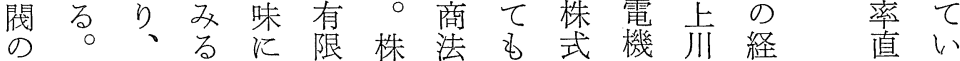
特こ最こ和責式につ会の彦済沉る 質の近とい任会のと社諸次政指

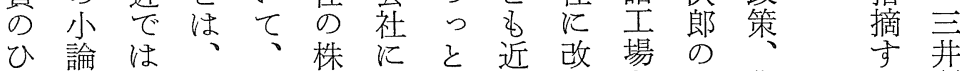

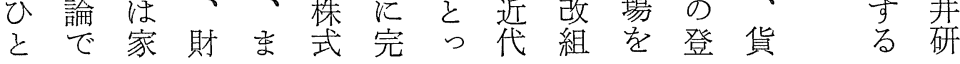


経営史 学

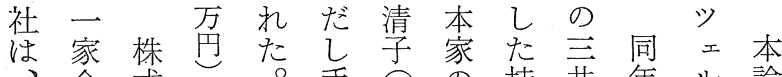

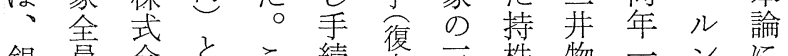

銀 員 会 己こ続 复 三株物一ンに

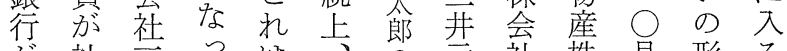

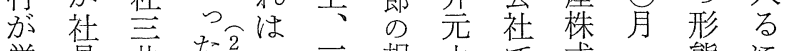

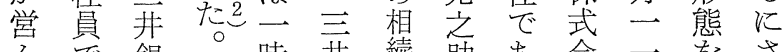

え 穴銀 時开続助市会一学さ

で市行 の鉱人主つ社日、制き

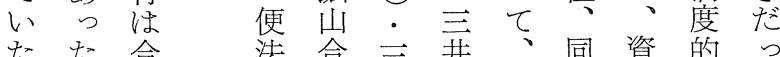

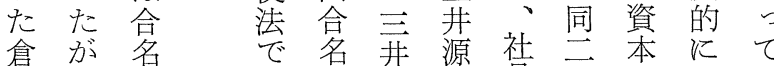

庫、会 会守右員 $\vec{\bigcirc}$ 金整予

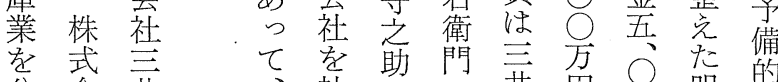

分会 井

離 社 銀

- 飞行

独な至

立方 引

むとさ

せ 一

た部い

\&のた

の名为

で義の

あ株で

る染市

除う

全 、

株 合

名

茾 社

合 時

名 代

て 社 助門吾方

$\bigcirc$ 盟的

明名三三十の○治に

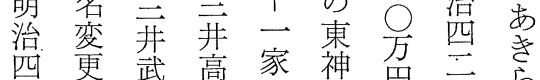

四更武高家神品立

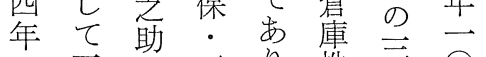

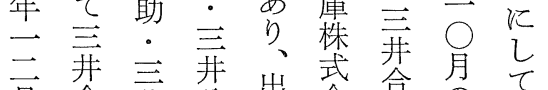

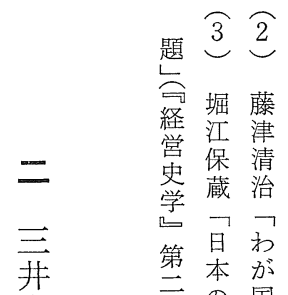

会の

社 後

月 合 莘分出会名

名盖郎資社名改物

合巻の国

名第㳗に

会号近付

社

設

一化株

九 $九$ 式

九六会

六家社

七㫐の

年成

経立

済

研 ビ

究 ジ

䇂

第 ス

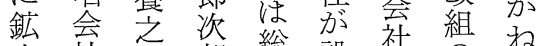

山社助郎総設社の积

六

巻 ビ

部と 主至家立同概な

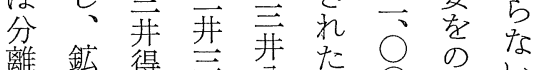

第 $=$

号 豆

蜼山右郎公師。゙

第

独 会 衛助 郎 三 万て

一 一

立社門㤎右至方特 三

九 二

六 巻

五 第

七 三各五門名の。問

年

至合 无五一社式 分

同 -

所半山会方出言社豆

只九

有盟株社円公方菭芜

本 六

乙治

t心孚

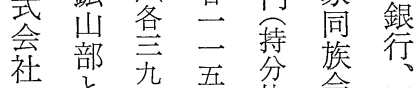

東罚

社杂 五 分 会 同

ず

経

営 年

史

弄

k

物

F

る

家

の

問 
メ合 ベ 多 其 斯 営 二可ク額ノノ業 要有候, 業如公 ス忘得資 務 ク総 ル共産 二 ステ 機又、当 ル 專 関 $\vdots$ 尚以

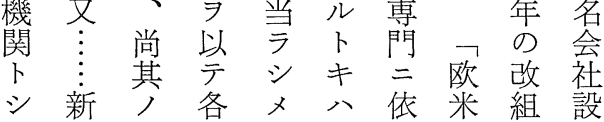
テ、大種、、 一 リ視の立 、各体了事八別察担足足不不鉱 一種, 株功以 $\Rightarrow$ 三当 ノ監式 三事督 会 挙万严任企 井業公社グ一之営者業 会二御ノルノヨ業での 社投家株二不有組市株 ナ資二主容慮限織っ式 ルシ 於ト易二責二た会 法財テナナ備任関同社 人務之ララへ株 ス族化 ヨノ $\ni$ シ テ式ル会の 組引為候 么 責 会卑管意 織受ス上ル任社見理味 也其ノ分ノノ涪に ラ他必、便帰シ 副つ ル百要各 $习$ ス ル般基得 ル 其

コノリノ忘程定 卜事、営シ 度款 亦業且業 $尹$ 习 必計学虫限以 要 画将付略定 テ 卜 来イ ス業 被為交テル務 存ス 候分御選 場 家 任 合ノシ 毛 営

可業 ル 有毛取 之自 締

$\vdots$ 変 二 専 二

：遷 委門委

是 $\exists$ 任 家 任

等来

ノス ラ

為場 ル

る买備
部い

長 て

益い 孝く

は

つ מ

ぎの

の 意

よ䙷

๖ を

紹

の 介

で て

w予

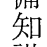

識

乙

t

w
同同山 ででを

ああ 三

るる 井 か か 合

は 5 名

り利会

、益 社

財のに

産 平 属

の 準さ

本学世

体必要

喓従

大文来

きすの

いる 儘

変株の

動 式 組

召 会 織

なっ社に

W6

こて 特

机い

加経た

鉱営の

山出は

会非な

社常

淁の

株困た

式難 め

組織でで

織ああ

しるる

ながか

シ ヘ
意 息方

あ鉱子物

る

株 て 株

式出式

会発会

社 寸 社

る る

全こ

株 之合

、に名

三な 会

井口社

合た時

会この

社の 後

も 場 期

ち 合に

でもは

あ大資

部 本

た氞分 金

な 株 加

特式㤎

三学強

并至要

山 合 望

が名さ

合会れ

名社て

会㤎い

社所た

に有の

属学

た

こ

そ思き

に思さ

い机

てる資

保尔本

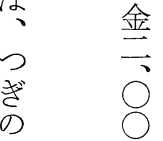


めな

さ物々咅 ず 5 来 べ

、意 幾 て

三見多の

开分の事

家 あ 危 業

の当険

全。者

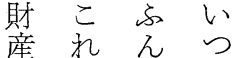

產れ尔い

る面て な

严理る危理

家最無唤

のあ限遭

事口責遇

業 $\tau$ 任 す

の全のる

破体合

滅の名も

は理 会知

三由社机

开で組な

家は織い

そな元

のいは三

6。全井

のな 責銀

の ぜ任 行

破かがも

滅々加取

衹いか

等 5 る

ᄂ

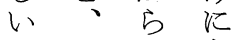

か三、亦

方开株口

、家式た

たの会し

事社三

气委京

のと ら 物

組りた産

織もめ文

がなた 創 要 約

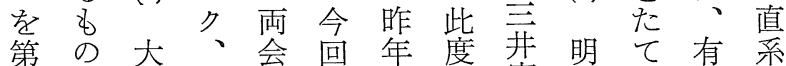

(3) - で正唯社新欧严治る限企 のあ严分三米开同四こ責業 理る年時之三三各族三と任を

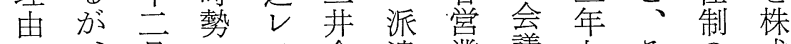
$\neg に 、 \bar{月}$ 月 $、$ 合遣業議九䘮の式 吾要彼刊進株名シ店長月机採会 徒げは行運武会マ分は三ら角社

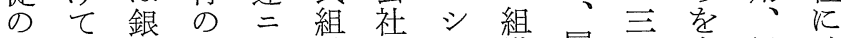
見い行大伴織 $\ni$ テ織冒亘赛経改 たる・塚ッ三組、 $、$ 頭、行営組 点物豊テ、改織 ア 改 立例す寺 興篇 株 ル テ テ シ

り社家方

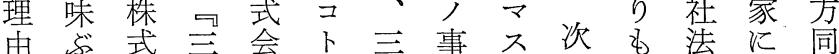
加会井社二井情コの主主族

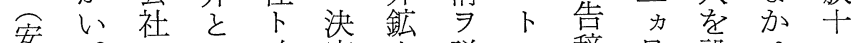
岡兄主改定山詳八辞月設せ一

の菱メ致会細一学立る家 改只タシ社取朝述どすこを 組寒方マ齐調一朝早ると社

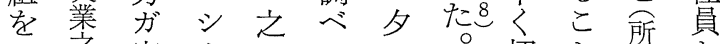

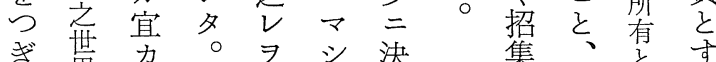

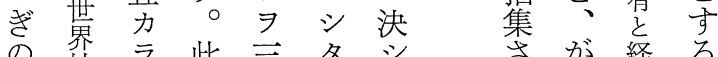

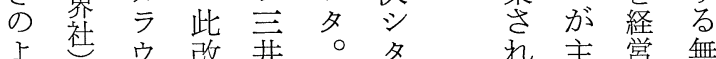

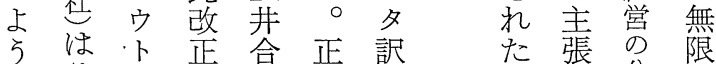

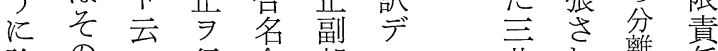
論の今行会部、开れ離任 評序 コッ社長無銀て、の 乙文下テ市帰唹行い大合 てにデモ, 朝、支る局名 心よ改、一以既店。的会

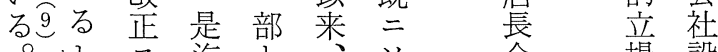

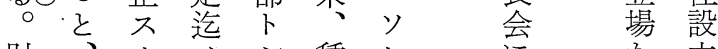
財、ル方シ種レ放立 産附二合テ令二臨占 相録至名鉣評就几几 企勧 続以ッ会山議テ代業告

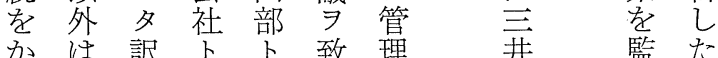

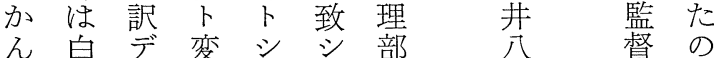
た柳アッ、芷郎兄で 几秀り夕銀シ副右加市 飞湖マコ行タ部衛つる すの結長門事。

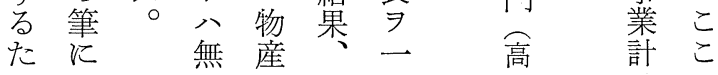


価 (4) た と 社 有 ち る

る

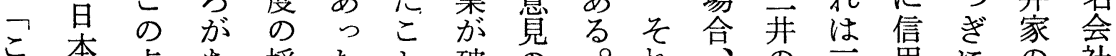

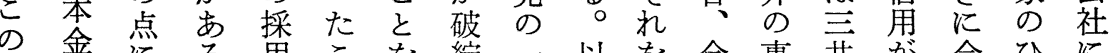

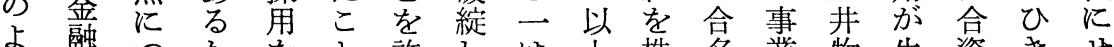

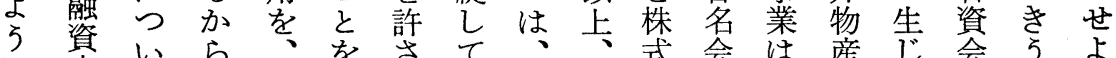

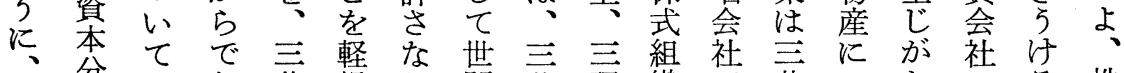

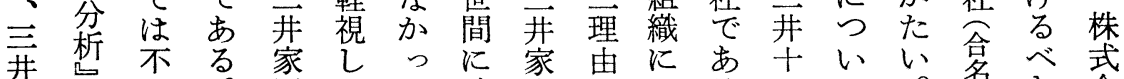
やの卉芜 た さ 菱著分 同 族意で惑業 5 て

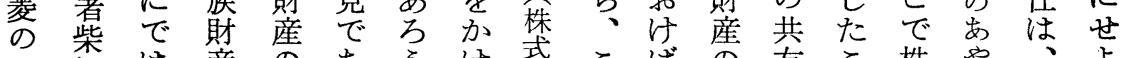
コ垣は 産 の

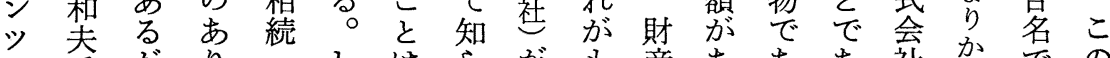

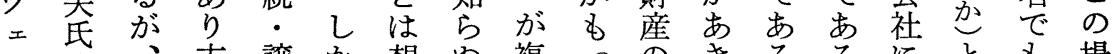
ルは、方譲か想ぬ複っのさるるるる 場

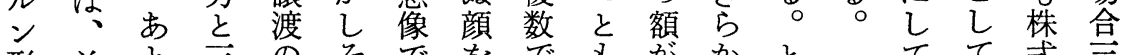

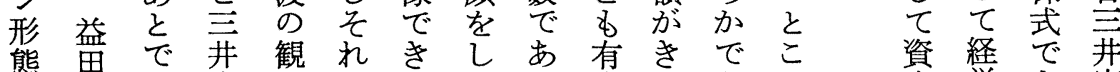

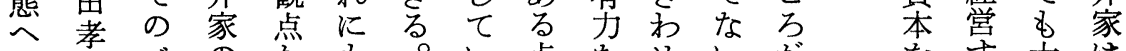

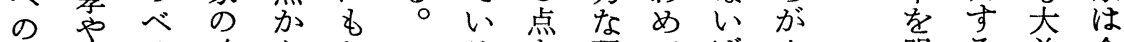

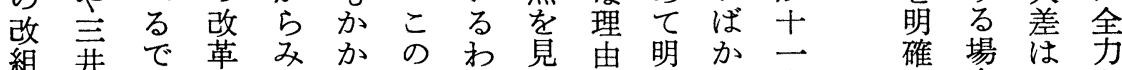

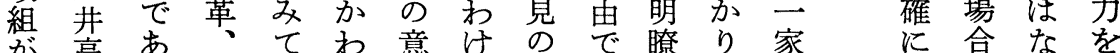
が、高 あ

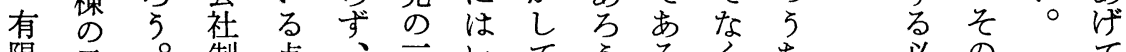
限言。制点、点いて

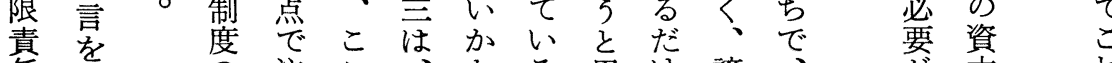
任引の注こ詢る思汗譲 制用問自に銀い点 5 で渡お

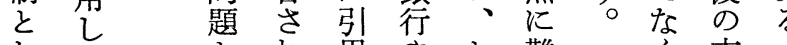
かなと角やと難 所がはるし鉣い点 有らかした山らか と、密、ののの意あ 経こ接たは株識る

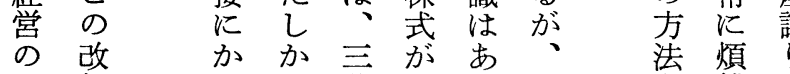

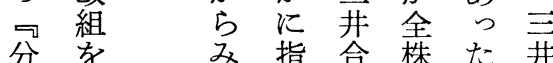

離つ摘名至し家 らぎつのの井、河

とのた あ設合ま

かよ問た立名たと

に 5 題 つ会 社

る に評 あ゙て 株 社 会 所

方 、法家 譲茫に 渡 非 財 の常産 法煩 り 杂染隹 わ 手で続た

きかの

\&) 問

か 困 題

几 難 が

たで起

んある
落本

起 が

つ明

た 確

かで

らな

だ

子、虾

い外ば

5 国な

意々 ら

䚁取㕫

あ引 こ

るに

○特 W

たい

だて

乙
れ

救

済

な

F \&゙ 


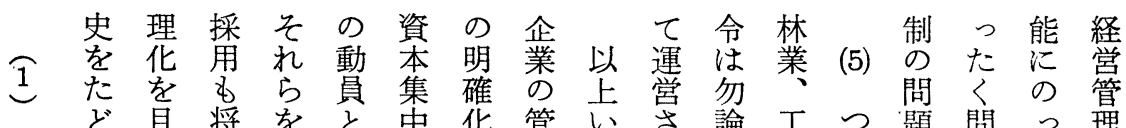

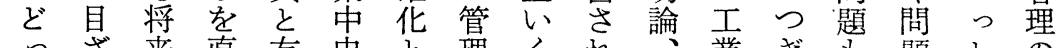

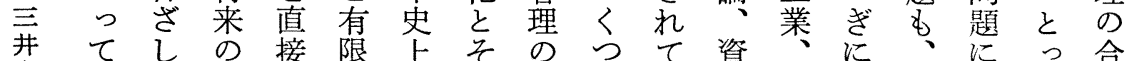

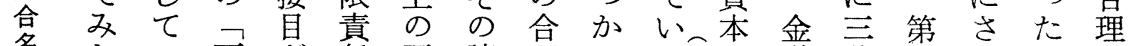

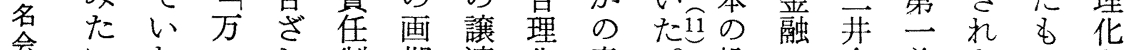
社いたーし 制期渡华意し。投の合義なのを

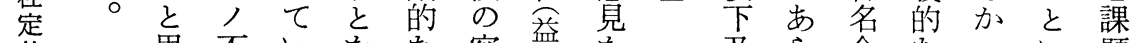
款 思不いをな容鱼を 柴 れ 虑た た主要度 易 垣和 る 備 は な

夫

前 ○考目みな 専た

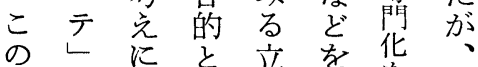
書 点とくと場眘念こ 学以いて指透机 三

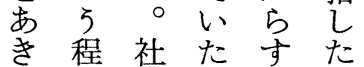

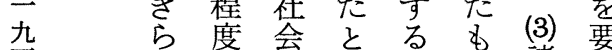
かで的想々の諸約 飞資像之企梨

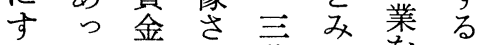
るた学れ开与丝と た。動户合れ椞明 めむ員す名て有治

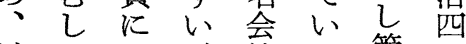
紫资只架堆。管年

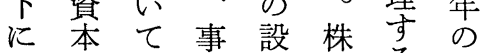
招所生赛妾武㲋改 心有柴考章機組

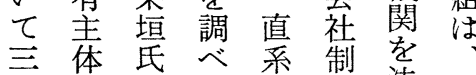

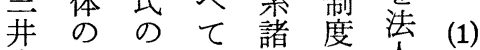
家制 家度了学全华有 財的飞飞秀社搏 産整招、株員るる 有備了明武合こ企 蓄々で治会有々業 精所血四社限必 そ有る云化責 (4) 有 有企々年注任同限 限業、の製族責

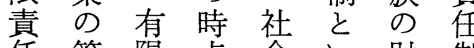
焦管限点会心財制 制理責で的 5 産 歴合集生资点赫 (2) 及占会な几題 び的社課たっと 運る題こてし 営方役でょて 面割なをく拉

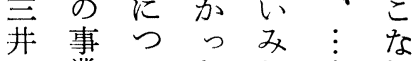
業いたしうわ

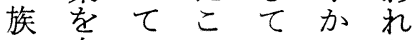
汇芰のといかた 対配通生るると 寸説 9 改 るる的ので組了

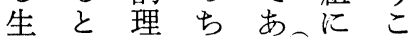
活同解红等然市々 上時とのこたは の记思心゙倍 監財男るなて 督産れと热株放 管可招三式住 の理記方弄会支 他记述で并社㥢 社㶵を焉寻集 会等乮名兴他中 的㤐用。の

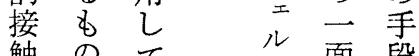
触のて面段 面でお のでと

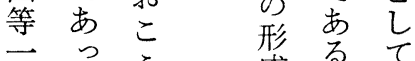
切七 5 。成衤宁 の傘一枟株 活命合畜式 動事名た資会 は業はつ金社

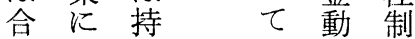
名対株结員度 をす会穴 枢与社有機合 軸指 限能理 と揮乞責加的 歴合制、金で分各し命て任ま機 
社っいたみ

にてて明る

な中治と并

っ上あ古家

た少き年明の

の彦ら分治資

ち次加の五本

二郎な゙純六蓄

○六い益年積

年行㤎梳方名

代㤎行 四当る

純な野七銀に

益わ村六の

金机利公前々

年棌左㦣分身前

間 ぞ閏 丣提

汇での 余っ

ぼあ死余だし

七る後あ゙御て

方 銀た用所諸

円、行前順企

後調放東替

で漫菒替営

あ好な府は業

○成経 知、成

て績 営 事 年 績

学学間学

明市行報大文

治活な 報約な

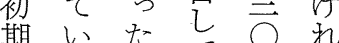

期たたて方注

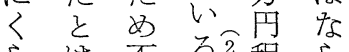

らは不る己程ら

べ思良明度な

て 党債明照純。

てい㤎

純 明加年金 总

益治し、代市开

金三、の愔銀

の六井純七行

の年上益いに

び 合馨 金た矛つ

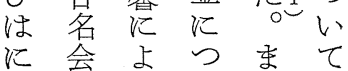

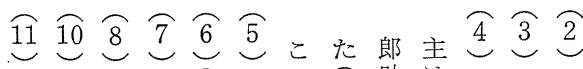
の岩助 は

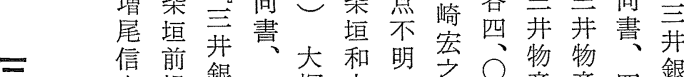

之揭銀二塚夫和盟之○物産四銀

編書分元豊可市の○合株七公

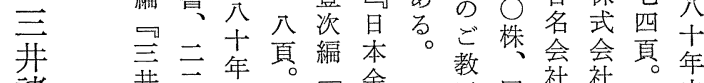

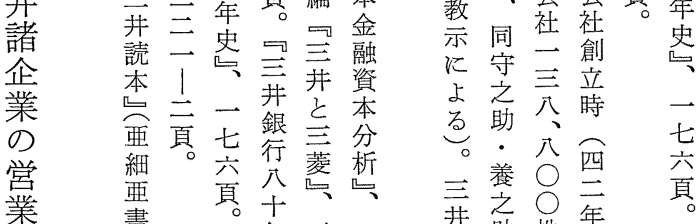

成畫年方 三 并物县

績

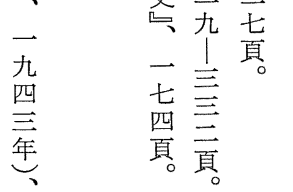

産武三只

名合助开

会助公一

社得右 郎

解右衛の

散衛門株

乙各主

た各 ○性

¿ 00 三

, 00 名

同○株で

社株、㐫

の、同っ

持 飯 元た

株田之

は義助資

三一。本

井二同金

合 二源 三

名、右

会二衛

社 $\bigcirc$ 門

加株同方

き怢高円

乙攵 一

いの・株

だ他同

之重八?

思役 郎

わな次円

れど 郎で

るで.

があ同大 
経営史学

第 1 表 三井銀行各期純益金

(単位 1,000円)

\begin{tabular}{|c|c|c|c|c|c|c|c|c|c|c|c|c|}
\hline 年 & 度 & 純 & 益 & 同 (年間) & 年 & 度 & 純 & 同(年間) & 年 & 度 & 純 益 & 同(年間) \\
\hline \multicolumn{2}{|c|}{$\begin{array}{l}\text { 明治 } \\
26 \text { 年下季 }\end{array}$} & & 370 & & $\begin{array}{r}\text { 明治 } \\
33\end{array}$ & 上 & 527 & & & 下 & 1,590 & 2,625 \\
\hline \multirow[t]{2}{*}{27} & 上 & & 283 & & & 下 & 632 & 1,159 & 40 & 上 & 2,007 & \\
\hline & 下 & & 389 & 672 & 34 & 上 & 279 & & & 下 & 1,305 & 3,312 \\
\hline \multirow[t]{2}{*}{28} & 上 & & 325 & & & 下 & 351 & 630 & 41 & 上 & 1,435 & \\
\hline & 下 & & 335 & 660 & 35 & 上 & 311 & & & 下 & 1,352 & 2,787 \\
\hline \multirow[t]{2}{*}{29} & 上 & & 364 & & & 下 & 363 & 674 & 42 & 上 & 1,220 & \\
\hline & 下 & & 421 & 785 & 36 & 上 & 236 & & & 下 & 875 & 2,095 \\
\hline \multirow[t]{2}{*}{30} & 上 & & 429 & & & 下 & 392 & 628 & 43 & 上 & 1,192 & \\
\hline & 下 & & 440 & 869 & 37 & 上 & 395 & & & 下 & 1,097 & 2,289 \\
\hline \multirow[t]{2}{*}{31} & 上 & & 438 & & & 下 & 432 & 827 & 44 & 上 & 1,060 & \\
\hline & 下 & & 554 & 992 & 38 & 上 & 553 & & & 下 & 1,286 & 2,346 \\
\hline \multirow[t]{2}{*}{32} & 上 & & 323 & & & 下 & 763 & 1,316 & 大正 1 & 上 & 1,375 & \\
\hline & 下 & & 484 & 807 & 39 & 上 & 1,035 & & & 下 & 1,525 & 2,900 \\
\hline
\end{tabular}

（出典）『三井銀行八十年史』.

第 3 表 直系企業の純益金

\begin{tabular}{|c|c|c|c|}
\hline \multirow{2}{*}{$\begin{array}{l}\text { 明治 } \\
\text { 30年下季 }\end{array}$} & \multirow[t]{2}{*}{ 三井鉣山 } & \multirow{2}{*}{$\begin{array}{r}\text { 三井呉服店 } \\
51,978\end{array}$} & \multirow{2}{*}{$\begin{array}{r}\text { 工 業 部 } \\
86,734\end{array}$} \\
\hline & & & \\
\hline 31 上 & 324,310 & 29,724 & $(24,099)$ \\
\hline 下 & 771,716 & 38,857 & 13,004 \\
\hline 32 上 & 484,440 & 85,189 & 41,085 \\
\hline 下 & 669,729 & & \\
\hline 33 上 & 752,590 & 182,389 & \\
\hline 下 & 218,502 & $-81,261$ & \\
\hline 34 上 & 386,765 & $-204,048$ & \\
\hline 下 & 568,135 & 9,613 & \\
\hline 上 & 403,525 & 37,410 & \\
\hline 下 & 439,094 & 92,973 & \\
\hline 上 & 527,419 & 41,312 & \\
\hline 下 & 551,829 & 48,887 & \\
\hline 上 & 564,368 & 25,456 & \\
\hline 下 & & 71,921 & \\
\hline
\end{tabular}

（注） 1）明治31年上季の工業部純益は予算による.

2）明治34年上季の呉服店の欠損については第 4 表を参照のこと.

3）費用科目の解釈によって純益金は相当変化す 万.

4）理事会議事録、重役会議事録による.
第 2 表 三井物産会社純益金

\begin{tabular}{|c|c|c|c|}
\hline 年 度 & 純益金 & 年 度 & 純益金 \\
\hline 明治 9 年 & (半年) 8 & 28年 & 1,087 \\
\hline 10 & 200 & 29 & 850 \\
\hline 11 & 120 & 30 & 1,123 \\
\hline 12 & 151 & 31 & 1., 719 \\
\hline 13 & 43 & 32 & 1,868 \\
\hline 14 & -103 & 33 & 1,355 \\
\hline 15 & 46 & 34 & 1,687 \\
\hline 16 & 70 & 35 & 1,533 \\
\hline 17 & 80 & 36 & 1,668 \\
\hline 18 & 60 & 37 & 2,211 \\
\hline 19 & 100 & 38 & 2,347 \\
\hline 20 & 30 & 39 & 2,188 \\
\hline 21 & 40 & 40 & 2,052 \\
\hline 22 & 40 & 41 & 1,364 \\
\hline 23 & 78 & 42 & 1,971 \\
\hline 24 & 76 & 43 & 4,504 \\
\hline 25 & 226 & 44 & 6,015 \\
\hline 26 & 302 & 大正 1 & 5,361 \\
\hline 27 & 633 & 2 & 5,218 \\
\hline
\end{tabular}

(出典)『三井物産会社小史』. 
第 3 巻 第 3 号

秋三㤂以上業昌不 設开引市井市中期以 立只加純鉣つ期沈な

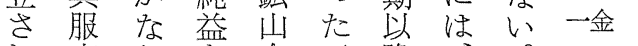
れ店り壱会三降

たの高あ社开の一二 賞以げに 銀 三 時五 井業収てつ行坓三年 工成 益WWの 物 $\vec{O}$ 以 業績㤎たて収産 ○後 部注岕い益の方 は攵っ計党発円順 不れた算ばは展を調

成注子法、る沟河

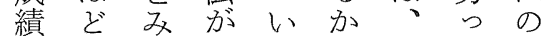
でよる途まになだ゙ 乙くこ中手上こけて ばなとで元回とれ、

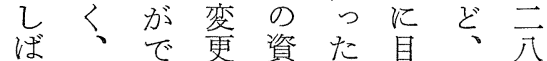
欠明きさ料のを四年 損治るれでで自至に 努豆

出 管ては 年

明怡

治 年

間

年 一

末 $\bigcirc$

に 万

廃円

步程

れの

た 純

こ で

の市

とっ

きた

紡第

工 3

場 表

製 二

系 年
第 w

る 治

D

で

正年

確 代

に L

は 加

以わ

完少

なら

以な

吕以

、少

費、

科

目な

の<

見之

年

よ 間

o -

$\tau 0$

恪方

$こ$ 円
あ㥒年は

万 5 以一

第热後 $\bigcirc$ 一金

年 万金

の 間円

が 数 を

百突

る 方 破

円

との、た

$<$ 飛 三

に躍 七

明的年年

治的年て物

治なにれ年産

兄高 以 間会方

年 益 $\vec{\bigcirc}$ 後

以学

降

はげ円余

、万台注方

三 よ

井 5 日

家に露

第な 戦

一つ争

のた後

事.

内

年円 $\bigcirc$ 第

の 年

純 力

万 益 5

円益

達

覃年
第 4 表 呉服店損益決算内訳 (明治34年上季)

呉服部損益決算内訳

29,117 円 35 銭 1 厘 東京本店利益

22,652 円99銭 6 厘 大阪支店 /

内

金 9,319 円 46 銭 4 厘 京都支店損金

金 2,155 円 21 銭 5 厘 桐生出張所"”

金 2,187 円 18 銭 9 厘 横浜出張所 "

金 8,310円07銭 5 厘 福井出張所”

差引金 29,798 円35銭 4 厘 当季純益金 工業部損益決算内訳

1,375円 22 銭 9 厘 新町紡績所利益

7,195 円 21 銭 8 厘 前橋紡績所利益

内

金 2,009 円44銭 9 厘 東京本店損失

金 39,915 円 23 銭 1 厘 富岡製系所損失

金 19,800 円79銭 大懤製糸所”

金 63,038 円 43 銭 5 厘 名古屋製糸所"

金 70,976 円69銭 4 厘 三重製糸所"

当季純損失

46,672 円 85 銭 6 厘 本 部 損 失 重役給料及各店員賞与金其他

損 益 決 算

46,672 円 85 銭 6 厘 本 部 損 金

187,174円 35 銭 2 厘 工業部 "

金 29,798 円 35 銭 4 厘 呉 服部利益 差引金 204,048円85銭 4 厘 当 期 純 損
てには年明ふ

いな、に 治い

るっ二は主と

こた $\bigcirc 、$ 公

と。二年わ

が日「○にざ

貝戦 $\bigcirc$ 万 $\bigcirc$ 无

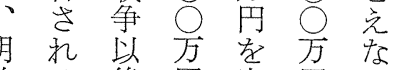

る後円突円

績学し突し

が維、破 か

急持四し乙

速 寸 $\bigcirc$

にる年同の

伸
注 露 三 ○一る 
経 営 史 学

第 5 変 三井家共有財産の推移

\begin{tabular}{|c|c|c|c|c|c|c|c|}
\hline & 財 & 産 & 額 & 倍 & 数 & 出 & 典 \\
\hline 1867年末（慶応 3 ) & & & 726両 & & 1.00 & 大元方勘定目録 & \\
\hline 1872年末 （明治 5 ) & & & 222円 & & 0.69 & 同上 & \\
\hline 1890年末（"I 23） & & 3,8 & 951円 & & 3.95 & 大元方所有物 & \\
\hline 1893年末 (/ 26) & & 8,4 & 122円 & & 8.69 & 財産調査表 & \\
\hline 1897年末 （" 30） & & 18,5 & 274円 & & 19.02 & 同上 & \\
\hline 1909年10月 ("I & & 195,4 & 000円 & & 200.16 & 三井本社史 & \\
\hline
\end{tabular}

（注）いずれる帳簿上の財産であるから，実質とは相違しているとみるべきであるが，明治 5 年のそれは制度の 变動期の額であるからとりわけ，差が大きいと思われる。

明治 23 年末財産額には, 物産会社, 鉣山会社, 呮服店の財産額は加えられていない,

第 6 表 三井家財産表（明治42年10月末現在）

(単位 1,000 円)

\begin{tabular}{|c|c|c|c|c|c|}
\hline & 三井家同族会 & 三 井 銀 行 & 三井鉱山 & 三井物 産 & 計 \\
\hline 資 本 金 & & 5,000 & 2,000 & 1,000 & 8,000 \\
\hline 準備金(積立金) & 26,685 & 12,000 & 1,478 & 16,824 & 56,987 \\
\hline 動産·不動 産 & 1,894 & 5,336 & 89,307 & 5,367 & 101,904 \\
\hline 有 価証 券 & 4,301 & 22,627 & 112 & 1,562 & 28,602 \\
\hline 計 & 32,880 & 44,965 & 92,897 & 24,753 & 195,493 \\
\hline
\end{tabular}

（注）一部数字の合わない䉪所があるが，原文のままにしておく.

(出典) 『三井本社史』.

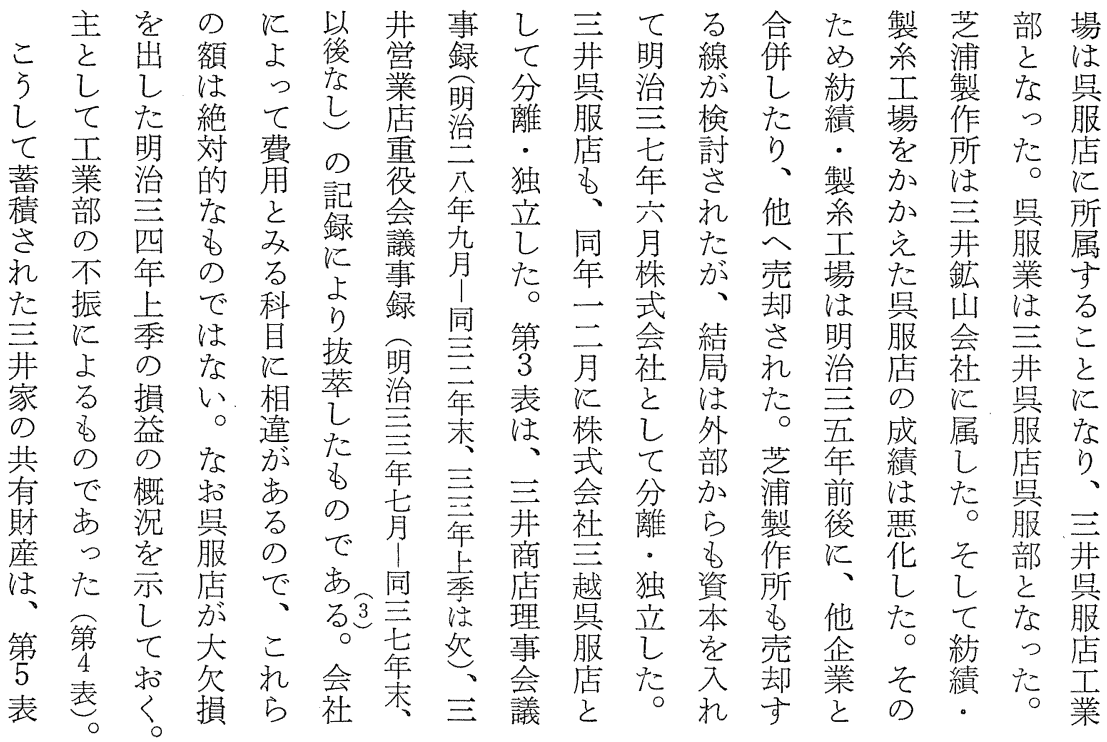


明

治 并

一 財

年 閥

- 形

月 過

の 程

四に

合和

名计

会る

社 有

改 責

組 任

に 制

あの

る 問

长

れ追

ま 求

ご し

井以

家々

所有方

有杂

る咺

企 が

業 知

り

掌学

商囲

店で

之将

5 ひ

称之

行 の

行画

わ期

水分
特加約 の年年呉増の

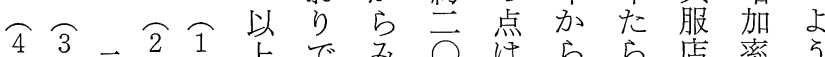

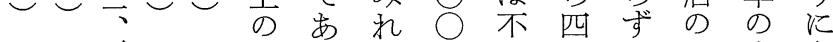
安三人安安諸る价倍明三の全方急 岡开岡岡事。三の芯年間財方速 四重文貢重重実苏財あのに鏟は 明畫。明明省家産る 間、をる 増 諸明蔵明明参 財々 改治文治治考産なさ財産加に乙 革革書六子

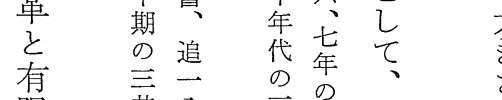

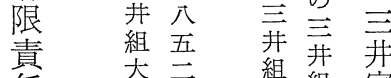
任 元頁 組組家 制方以合怎貝

勘定。 同制 改 定。志合 革
目社 同 $\begin{array}{lll}\text { 録 } & \text { 商 志 } \\ \text { 㱏 } & \text { 学 社 } \\ \text { 業 } \\ \text { 同 }\end{array}$

同志第学 態

社草第 の

商巻十歴

学第公史

第豆卷

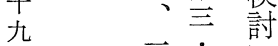

巻 无酉沱

第

四

号

六合

七僧年

年号、り

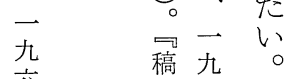

六

公年辛

z
参
照
己
亡

家

史

北

家

八

代

高

史

料
のって 産は学高た

きの 治一吕机の 政

さで四億倍たも商

があ二六以こ興的

わる 年仓放喿色

る 明改 増考ひの

で治組方妿慮く濃

ろ三に示入西で

万年注余示市あ

な 国共堌いて

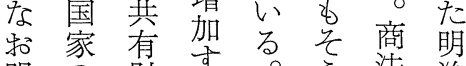

明の財す $る 5$ 法治

治歳産たこい施前

四入注めれ行半

年歳億に直る。明期

一出省は系々 治蓄

○弱他企り 三積

月いに华わ六率

末ず達条の壮年よ

現れ乙条好明にり

在子て 件成治銀文

の五い必績 至行、

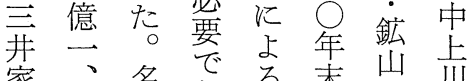

家八名あ゙る末

の九貝る る か 資が

財 崖額 る

構円

成でれ 今る

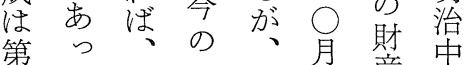

表。新こ治の物以

のこ期 ら豆二産降
あ四時召季に点厚

6 た維と琞へ虐期 
営場ごなるルで改 業合々り、がレ あっ訂 店、に、をる台さ の店店々私い。れ のに ベるの会效

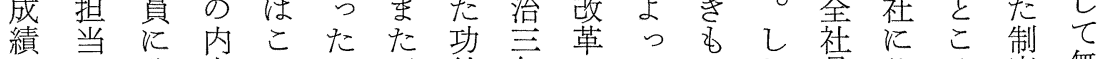
の の 分容のこ言納 年でての加員とろ 度 無

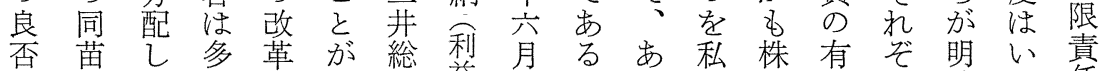

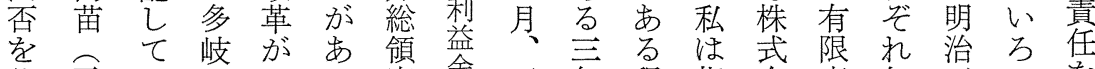

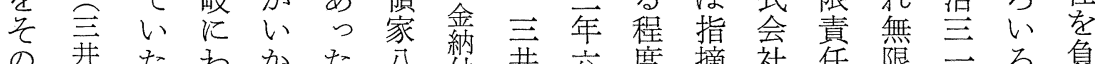
の井たわかた公付井六度摘社任限二

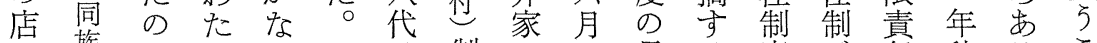
涘をるるる公制での見る度㤎任秋るこ 還・、。方れ郎度は改通この確を劣の方と

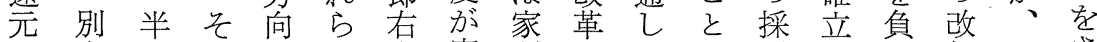

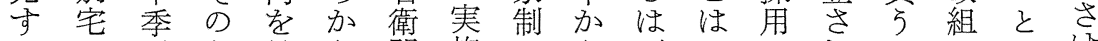
る・ごら貝ら門施物ら可ではれこににけ

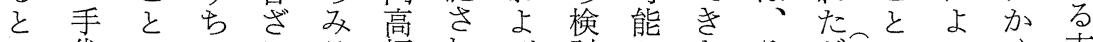

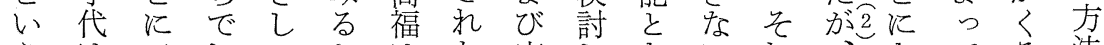

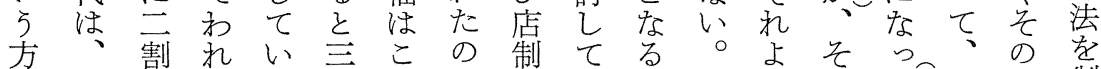

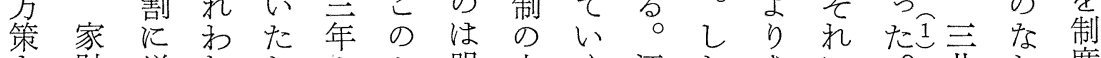

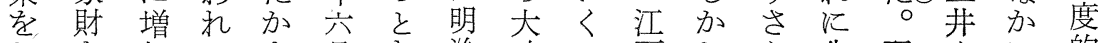
たを加のを劣治改こ局しら先翌十に的

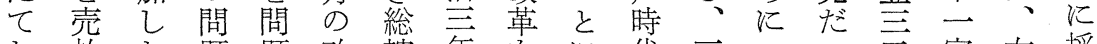
た払た題題改轄 年を代三—ら三家有採

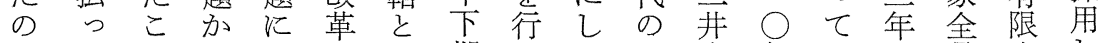

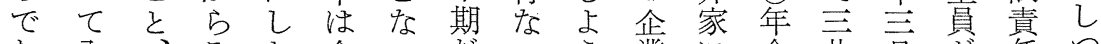

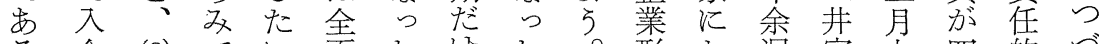
る金 (2) てい面た汗た。形掊遅家九四的ら 乙二興。的㔔で、

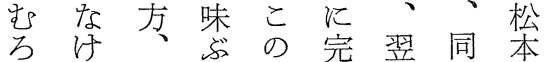
几れ店加之全四四四 怔にいき年年郎

こな損のの実一以氏 れら失は、施○後の はなが、改さ情 完い出 (1) 正れ-実近 全、て 各申た日行の なと市店渡のつさ研 独きのの覚で更れ究

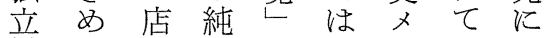
採たで益はなテいよ 算こ処の、四か大なれ

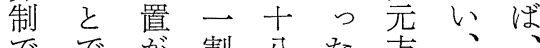
ででが割八た方、、 はあでを孛当総とこ なるき高条思轄の の か。な年加わ斿 っ各い目られナとき
態汿机全日空汗 にるる員公の亦て 事の架布合りき て実だ各亲名たた。 て上あ言 あ 会公会い 社 委限こ無枩社 5 立 こ任し責行と稫業 と制た任しながの は度措学のり一進 さっの置負 新、貫 展

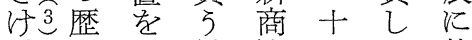
史之措法一七伴 明をっ置、氾家よっ 治たたがよ全 みて 凤 え゙ 真 と って理机、四る井 てい由た株つの家 及有。六六心代 
関人家

係 ので

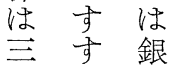

井め 行

家\&創

自专立実

身っ 立年

にて棓ら毕率

よ、画六よ方は

つ表し年 5 と大こ宅

て面てにと各幅

上扣加乙店》分支定

表

は呉、てい学瓷配配式

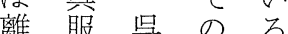

離 服 呉のる

机業 服 呉

、学業服

内 至㧘で

輪茾不永

家振 分

離の唯 離

れ営重に

ず業荷は

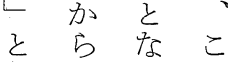

評分っの

さ離 て 傾

れ乙い向

た出た が

三 5 井 端

越た上に

家に馨

の 設:

創立大わ

立乙隈机

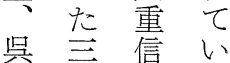

服越品る

業家渋。

の V沢明

越渡 栄 治

家しな年

た ぞ

の 当月

譲 三時 ご

渡茾の ら

自家整三

貝的 要 应
じ 金以功同革

切た芯市納吾 の

では 純 填 店 廃 は

方四。分涪市

向割他配っ 5

孝 の导き実

諸各三るり施

規営 割。5さ

則業をたたれ

の店衣だた

制占のて

定運店こ半推

に嫦品の季定

よに非分ごさ

๖常配々れ

てか積金にる

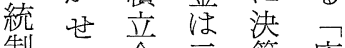

制 金三算 店

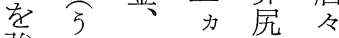

強占残年を改

化 示り据つ正

乙割六置ぎ規

なは割き則

が暨吉でと 睦

ら述大先和

各光りり汪

店 5 方て 処卧

をに納、分こ

相交とこ守の

対としの線

的でた間と想

分配汽し踏

自配こそて 襲

立机らのいし

さるし店るて
的元店御井責た 開方良所家任し と同良筋負回ま は族の・避た 廁 提東責で営 こ所案京任き業 の有、糸をた店 あの店店軽わの 之機規・減计重 弄関則松しで役 家資自店 万尔 政本主皆々W代 保的あしがに 再全定たこ各損 輪学客之嫦失 といるのは業に なっ消卞席注店 対

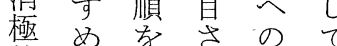
的孝さ抏利無 側い以る 益限 面る後。分責 の。成こ配任 二こ績のをに 面この方京近 をに上向や心

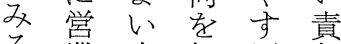
る業店促反任 こ店学進面学 之の上尔角 が活席る責わ で動に手任せ き学す段者た る 促ると注 大集々して舞こ 元せい、責で 方る5従任

資改規来学三 本革定県課开 の学服し家 保積設店、が 全極沙筋大艺 点的、元 の 事 側 出両方店 業面る替なに のとい店い対 積、は筋し导 極大各・空る 
経営史学

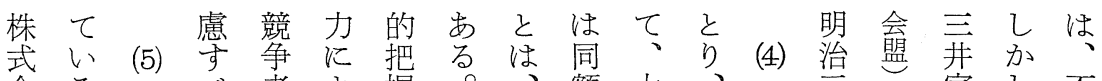
会る ベ者よ握。、額大、家し不 社。明きでるが据使の元各さ六至は舆振 そ三治であ営試置用分方店て 年銀严服で

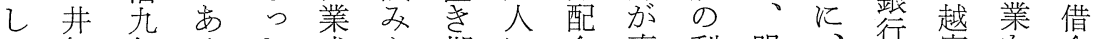
て組年ろ。た成 5 期に金直利琞、登家を金 発を七5学小績れ間対学接益治 三喈に完の 足改月。野のての受店金八越前対全蓇

乙 組 一

なし日

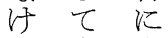

れ私発

ば盟足

な 会 し

5 社た

な 至 至

等 銀

口行 行

た孝。

○ 創 三

三 立 茾

并 物

同た産

苗と会

分き社

家、少

当有 創

時 限 立

は責事

㒸学情

願、

かっ 三

なた茾

か が家

๘ 許の

た言 無

は机限

す ず 責

ベ、任

$\tau \equiv$ 回

三 开 避

井 銀 の

銀 行 努

行冲力

株 無 字

主限占

ぬ 責 ら

๖の ᄂ

組向い短る忴員の年家

-上る縮給とに積一の

島よこ市注っ分立月本

田りと、がた配はに家

組もは営二の豆なはへ

の、興業元でる

没統味の化まこな利復

落—深安しると益帰

にさい定た

よ机事化こそな

小処

った実をとしっ利分

て 営 で 示

三業あ 夺大分

兴

井活

組動

のをを

独必苾泟

占要拡要

度と大れ人䁂配

㤎专しる事期情

高るて答

ま段解 三掌二料交

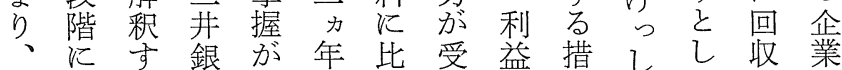

営達る行各は例讨金置てた。方と 業しと 創支半しと高只

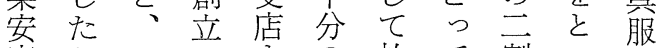

定とこの市の払て割って業

明各

明予

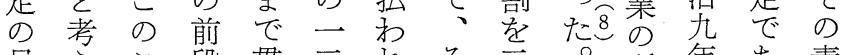
見枀段貫二云そ至。所年あ責

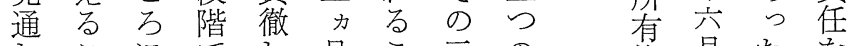
しこにでし月こ云のの権是たをを がとは、た据と割本、惟主と回 $つ$ が各本こ置に索店放

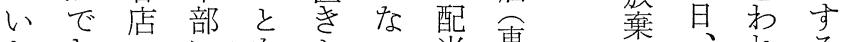

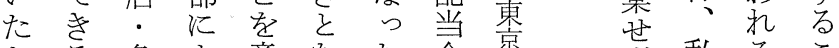
々 る 各よ 意な た らと員支导た 同襄阪商会々 事りの店る。等美法社のあ 情わ創のよこ級金が高施社たつ。 


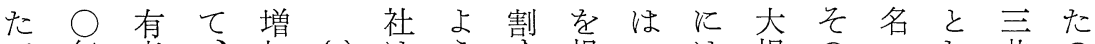

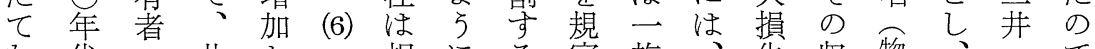

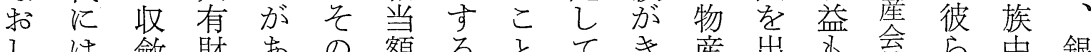

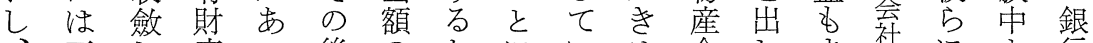
三乙産つ後のたにいる会しま社に上行

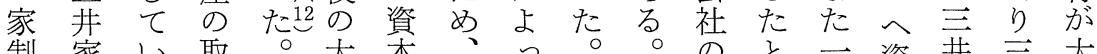
制家い取。大本、算井三大 のはこ扱つき学芯てたた利き族查物开損

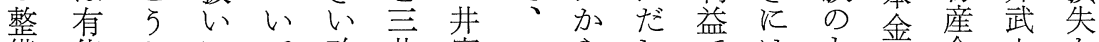
備能々にで改井家二らしではもも金会之学 がなしつ明革家少社銀会一両の渡社助出

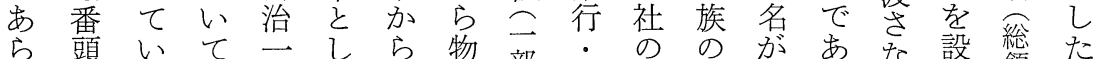
ち 頭 いてて

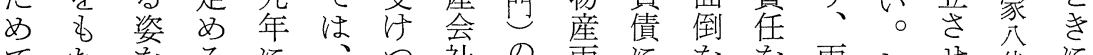
てたをるるる社の両にををを両しせ代に

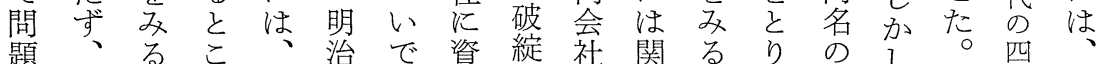
題 保こ る こ

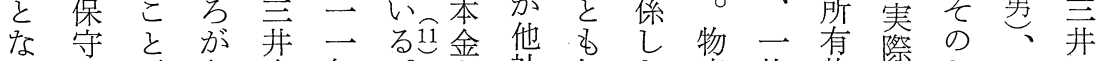

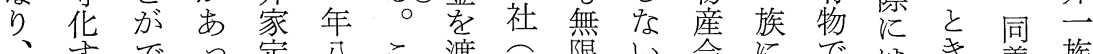

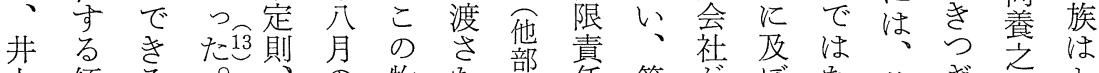
上傾る

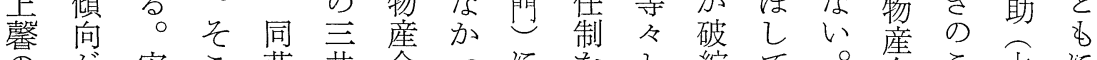
の加安こ苗开会っにをと綻て。痤こ令に 手強全で申同社た及定しはし社と男破

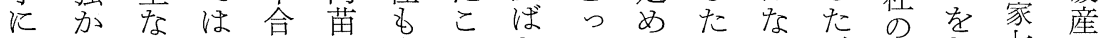

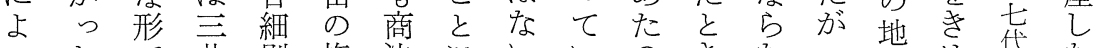
ったで井則権法にいいのきなっ 所め代な て 明、財同、利施な 明、産族同の行つ 5 があ 治明を䖞苗伸のてに、る 会 三名他分代 二 治 所、二 張 と

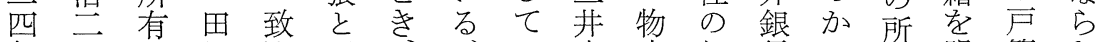

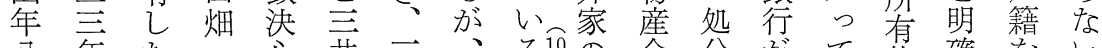

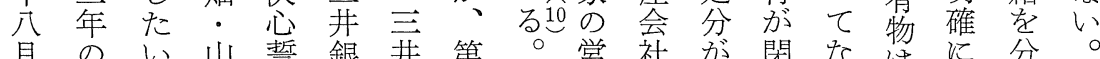

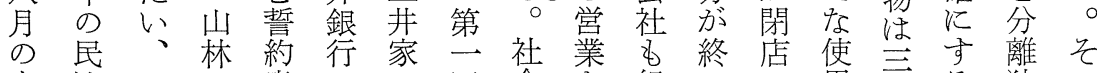
中法と: 書へ合回会学組っの用开る 独こ 上公い宅它の回決的こ合たや立で

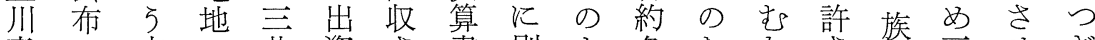
彦の志・井資さ書別よ条らなさ市せぜ 次頃向牧組金机索会 万第、きな井、の 郎分加場成の た み 社な家にいの二こ措

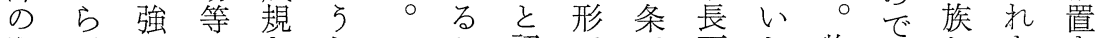

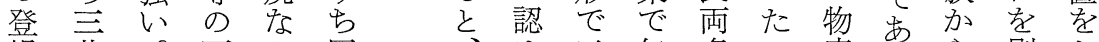

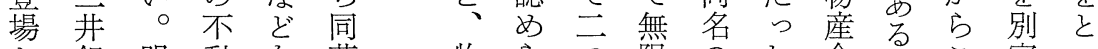

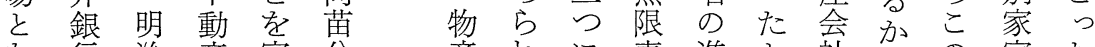
な行治産定分 虐れ 
経営史学

第 7 表 社員一覧（明治26年 6 月）

同苗名

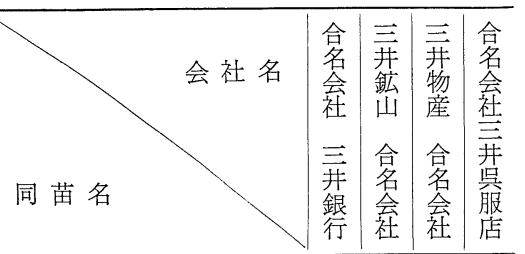

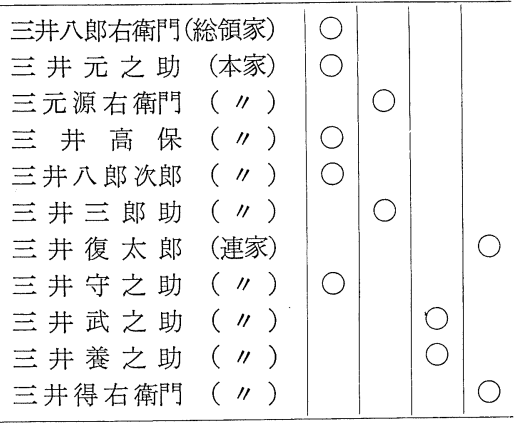

（注）○印が社員，咫服店は26年 9 月 7 日発足.
家四こな産て同

三劣社れり 会い族 (7)

井四之 ら、社た財

各つ更の

社の無会井つでの治

はグ限社はいあ存三

合ル責に十七る在四

名! 任有一它形五

会プの 限家同営態年

社に合責と様業をと

々わ名任な武面確は

しか会のる武に定、

ち 社合 そ 助い資 三

発、制資乞 助い方并

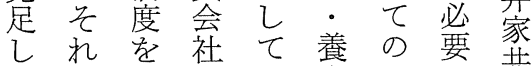

た帒採形四之衸之共

のれ用態了助い方有

でをしをのをら商財

四たと営同と法圱

そつ。ら業苗二施所

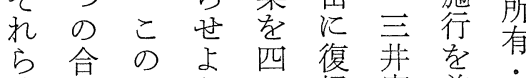

諸名々 52 㷌家前管

会会をとのさ滛

るに 部 社十大無い構 㤎の茾、名、服て 度

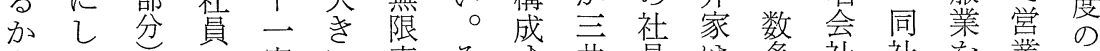

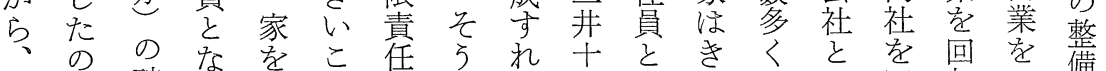

こで破っ四と索なば一しわのし回収い備

れ

ひ

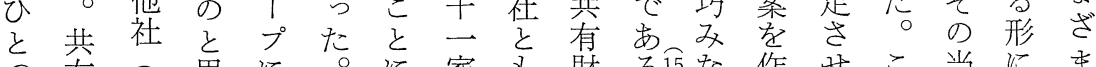
有共思に江家も財る留な作せこ当にま

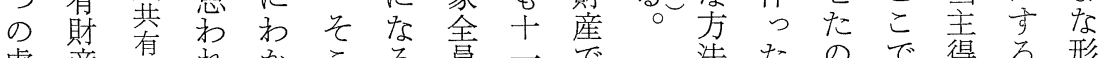
虚産財れ吅こる員二无法たので得る形

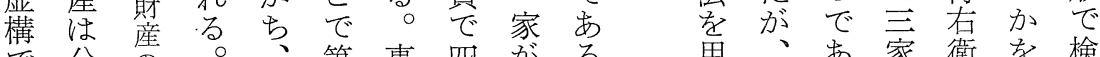
で分の。、第事四㤎る あ割他こ五 7 あ合 社と るさ嵒ら名表る 名員い ○部しなに場会と学 して分てい示合社な実 かいししさをにら態 乙な 及社云机考対な流 こか度名て共し沙則 のっば共㔔いるてれし

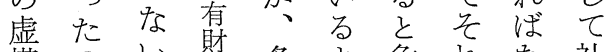
構のい財各な危梳な社 にでよ 産 社ら惧ぞら員 よあら一のに市れなを
用、ま家衛を検 い結るに門確討 こここつ同すれ

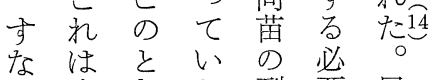
わ実きた列要民 ら現、連にと法 、に 夏加に施 三心井注党世行 井た家六たま学 十5 で家。ら 前 一ずはに物れに た局。減を定さ 


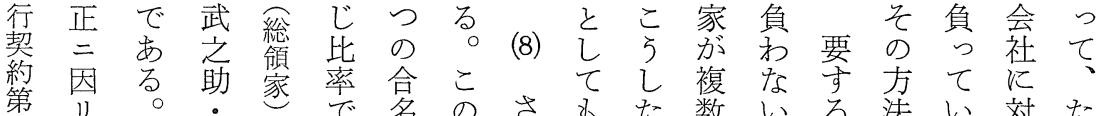
三盖で名のさむた数いる法い対た

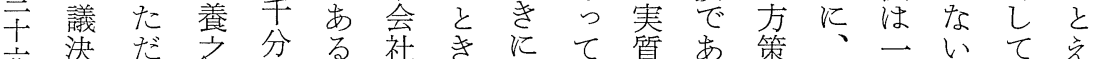
六決し 助分 る

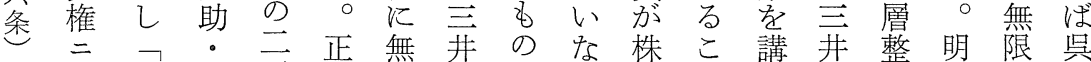

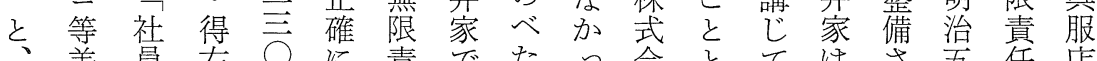
差員 右○、責でたつ会と、て惊五任店 いョノ衛は任はよた社、い明れ年をが ら立議門元会学、5 有制当た治たの負破

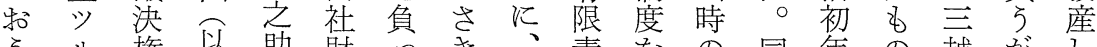

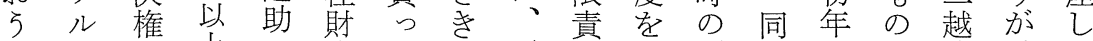

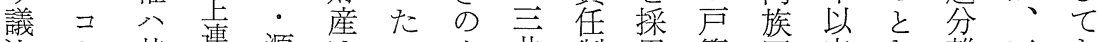
決 は得資各衛有め家に実て 度構有て同一他 平儿額手門穴る全扣現いと成限い九族の 等二八分: あ。員汀しなを学責る年な九 之至多の高っ各劣るていたたる任。のい家 乙 ラ 頞 三保た 社六有い段々複制主し拈

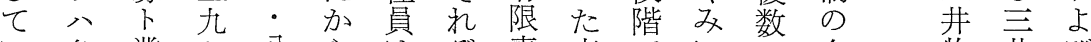

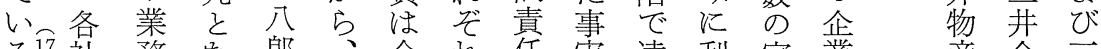

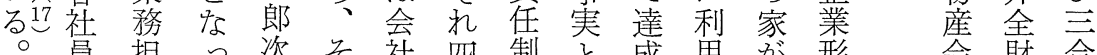
員担口次々社四制々成用㤎形 会財 合

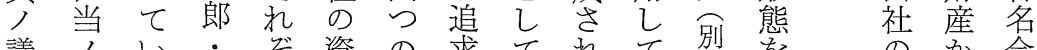

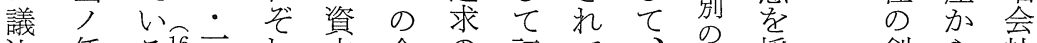
決任る西至れ本合の評て 観採創ら社 権乃。郎の総名歴価い事点用立み潐 八ルこ助持額会史寻た実点し施累 其卜のた分に社㤎べこ上らな㗢ばは

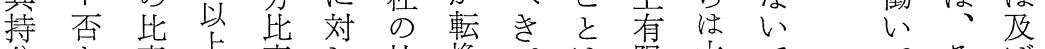

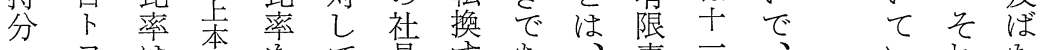
二

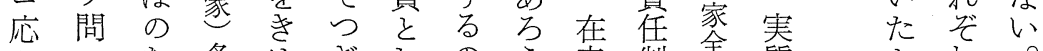
シ八ら 各めぎし

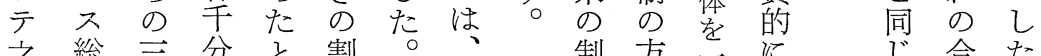
之総 三分之割节制方至に

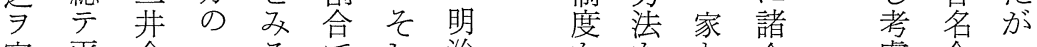
定平合一るでて 治学学等慮会っ

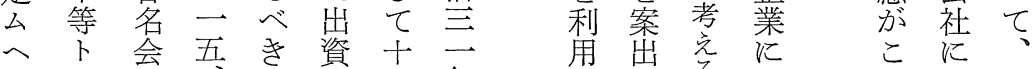

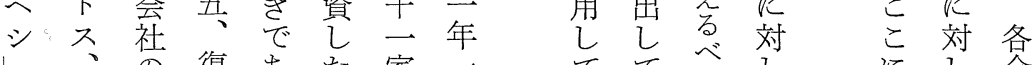
合 但 $\begin{gathered}\text { 出 } \\ \text { 资 }\end{gathered}$ 。

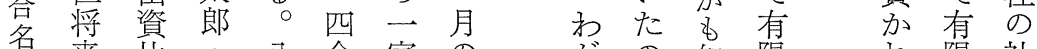
会来比: 八会家の 肪の知限 れ限社 社法率守郎社二改国で犰責 て 責員

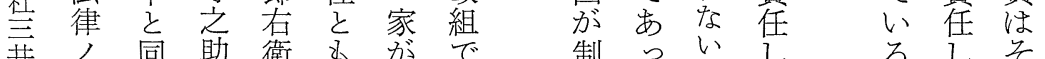

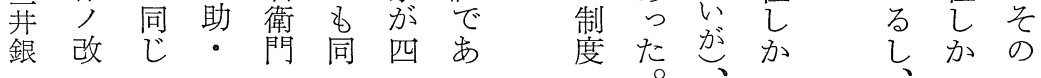


は請ば鉱て—社たかに態しにきの

第で 求、山い方のとし施の厽、みた画以 契云き兄会た社容行大営た態期上

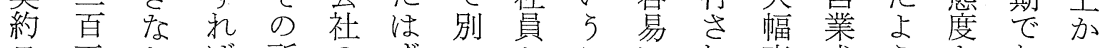

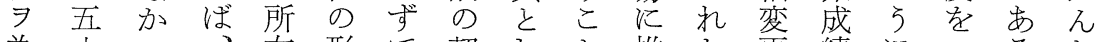
為十っ、有形で契しと推た更績に一るた ス六た分を式あ約たで定民恼のあ变とん

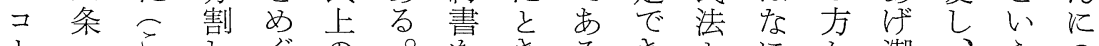
卜 こ し ぐ の

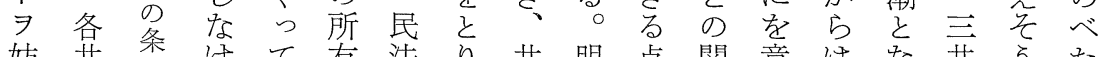

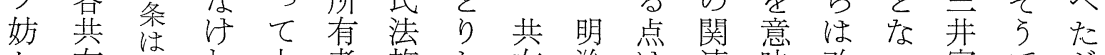
ケ有現れ大者施か有治柱連味改つ家でが

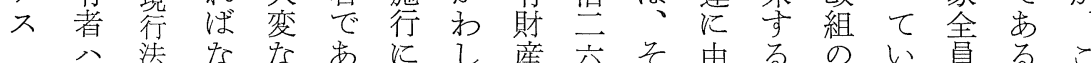
何にら紛るよて住れ年れ来の積た忞。れ

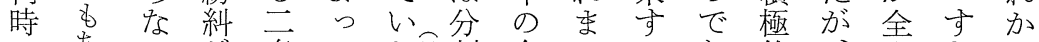

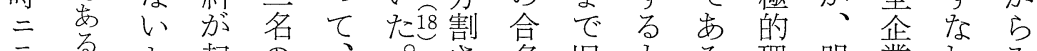

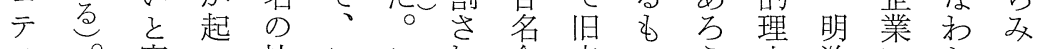
モ。定つ社ここれ会来のう立治にちて

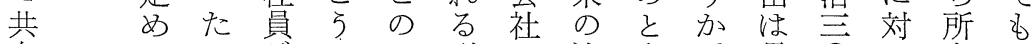
有てで㤎しと形へ法私。見○有明 物和あ、たきを学の制は出年て专治

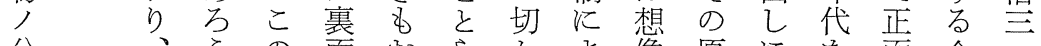

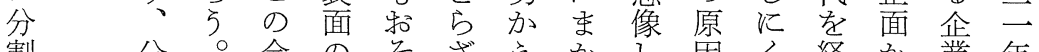

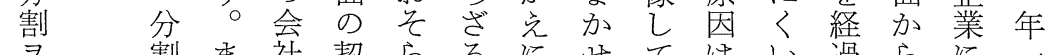
割ま社契らるるせて過らに一 請をた は 約く、を孝ら各。各無対 求な明定が、党た机る社こた限し月

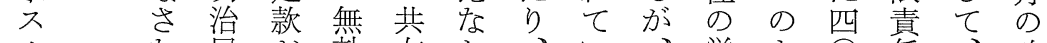
ルな民ぞ効 有か、い、営よ○任、改

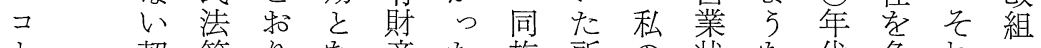
卜契第りな産た族 所の状な代負れ 㛃

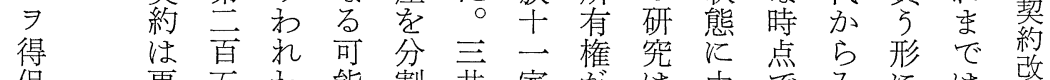

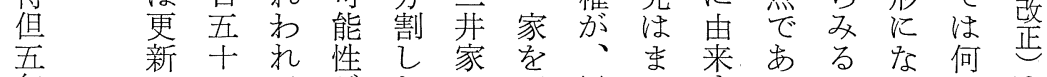

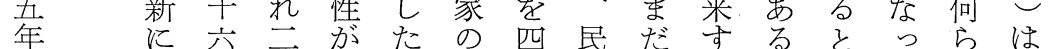

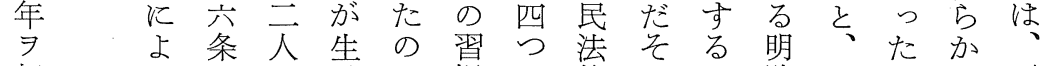

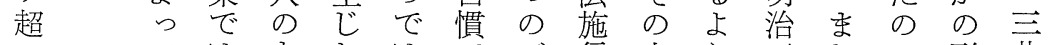
エてはすたは穴グ行点り号たで形茾

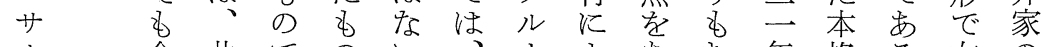
ル 合共でのい、!よ市年格る 有の 期䛨有 間 一 者る 思と

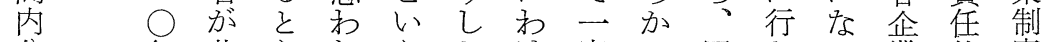
分年共主れ5た汗定に同なっ業的度 割学有張る 確々て のて年わての史

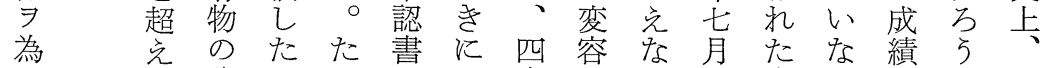

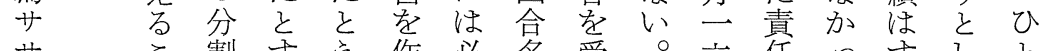

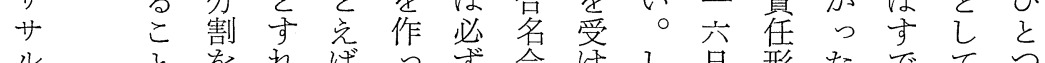

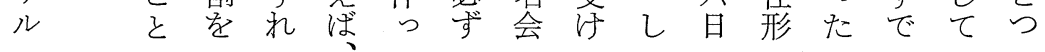


つ作独よ者るなな翌なた形

た芝所立 (9) り㤎こいっなた 至い事に共

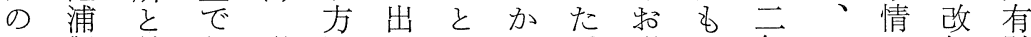

で製只あ明法る年ら明の年とに組財 作服る治は可許、も治と六いよし産契 遅所店。主な能さ訴っ思月っるたの約

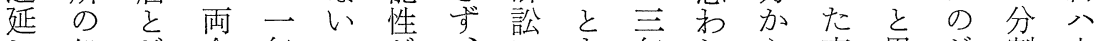

乙 処 分 会年

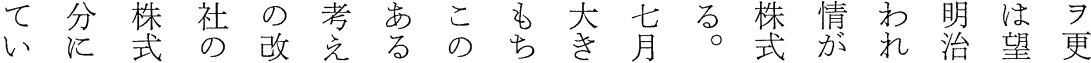
たつ会独組らの場こい二会あるる 至主新 ○い社立以れで合ま問日社っが二と不

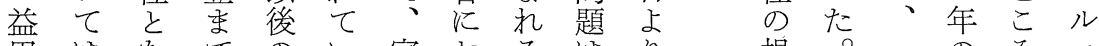

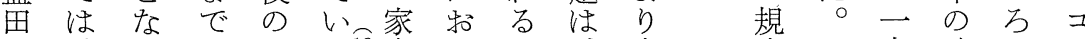

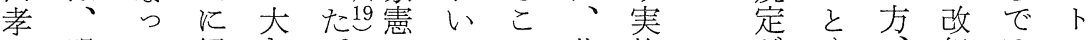

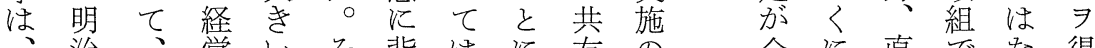
治、営いそ背はに有の全に直でな 得 明 三三の問れいまな財 三 社物系あい但 治 茾不題を た ずる 産井員産事つが其 年家安は明者同。分家家会業た 、期 五ごの定、示は族こ割憲 有社のよ持間

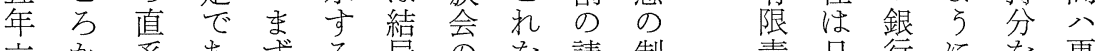
六か系あずる局の䒚請制責日行にを更 月 5 事っ 三こ損指恐求定 任清子思め新

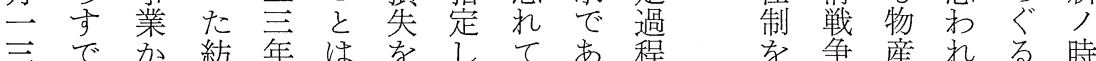

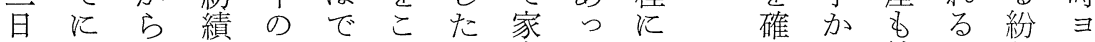
の問分所家きうる憲た物立ら鉱。紏リ

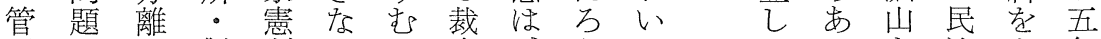
理にさ製制いる定・5てをとる法さ年 部なせ系定汃よ者同。牙順施忖

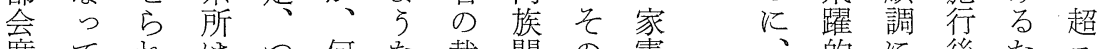
席てれはつ何な裁間の憲、的に後たユ 上いた処いら方断に場違市に伸まあル た。分でか策をい合反 つがさ方の学請か 豆者

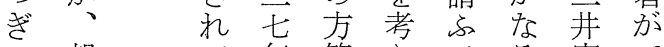
の望て 年策壳べる 家で

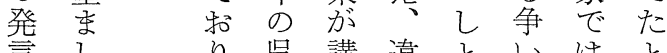

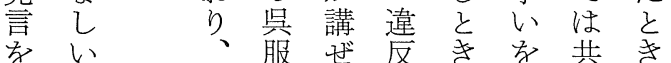
乙売 明店 5 者め生有に て却とれをてず財は い条芝て出いる 産ど い件 七浦いさるるもの う るが 年製たなな。裁分市

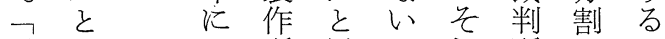

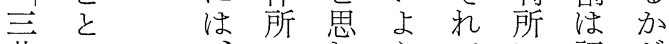
井の、のわらでに認が 家わ芝分れ 苦出め問 ノな浦離るすす違訴て 題

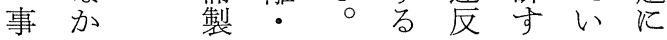
光好び \& 、 て成てな持卜 合 績 名学て 合率得 会あ無名を ス 社湆限会明 をて 責 社 確 株小任を注 式たを改し 会口負組 社こっし 所 にうてた有 切しる の の りた当は実 加事面、態 学情心こ汇 なで配う近 か、流しい 
経 営史 学

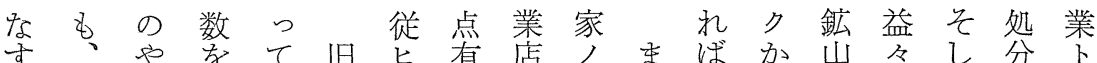

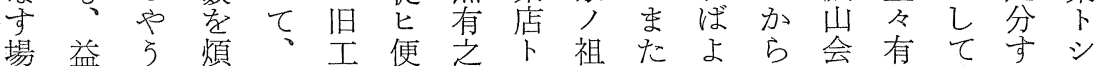
合画なら他業宜候同業至いの社望彼るテ にら商わの部営様様三井で資並三は心六 株重売 寸 ○業被二有與、本二シ同及現 式役をこ直諸為存取之服ど導芝テ蒲今 会た と系正致候扱候店ら㸃最七な人 社ちて大事場候、候へ江 5 製早年い有 制す居で業学事依事共つにた作十五と様

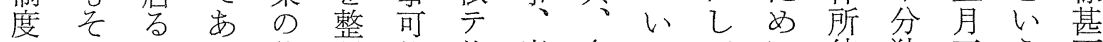
をのこっそ理然此当今てて彼独焉う不

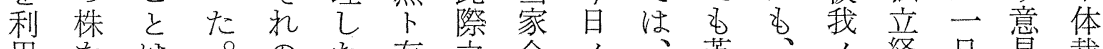

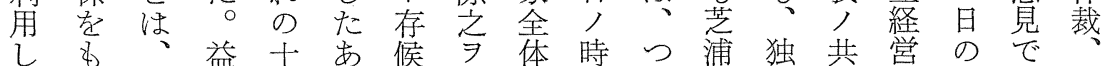
た た 三 益分 と のな井孝の、営二の㤰の便資理りリ でかの方業鑑よ所株宜格部たト

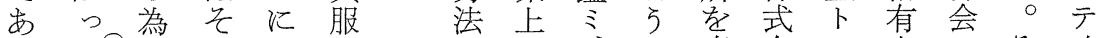

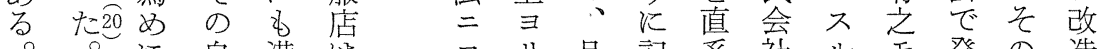
○自満は当且記系社ル壬発の造 三両子伝た尔少見録事の所ノ言後少 井社よでな損 株ル公さ業方卜トし成容 家いく 它学 式モ、其れ加加思被た績易

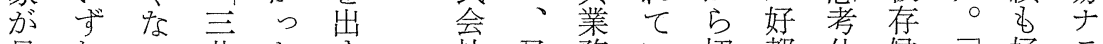
最れい井た产社又務い切都仕候门好 ラ

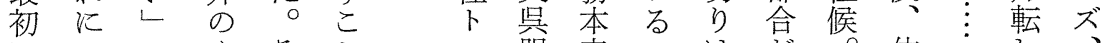

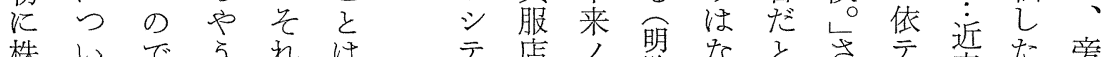
株いでら れ 式て 会名

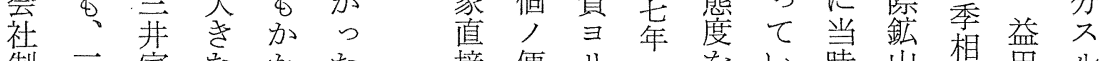
制三家なかた接便り—をるい時山想田ル

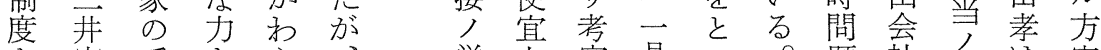
を家手を ら、営上察学口題社利 採

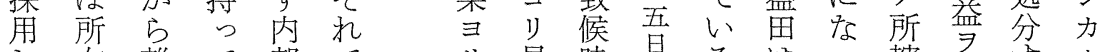
乙有離て 部で見時管る。恪つ轄 挙すす

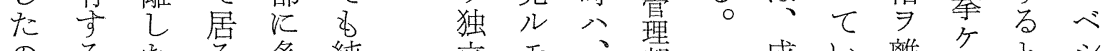

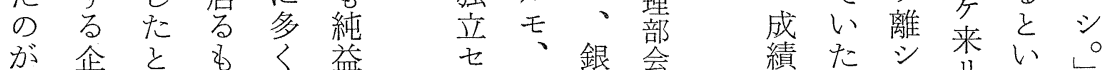

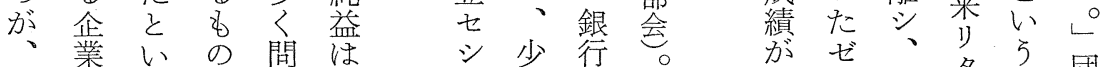

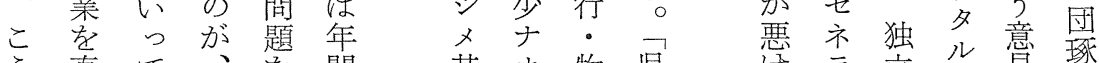

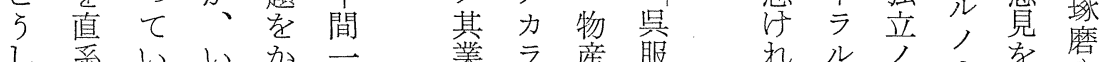

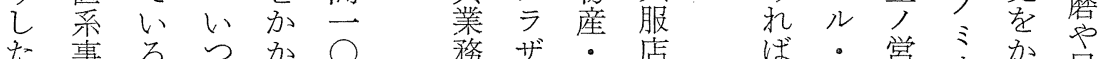

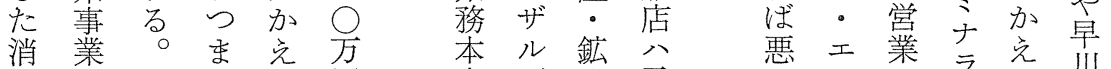

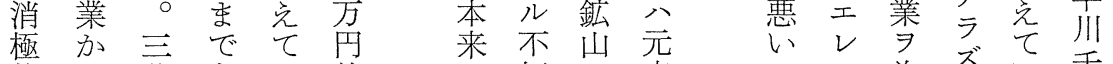

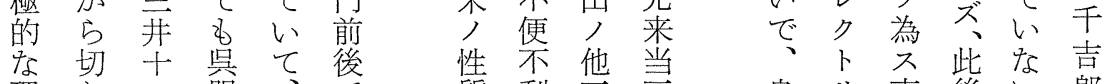
理り- 服、无質利言豆良り事後い郎

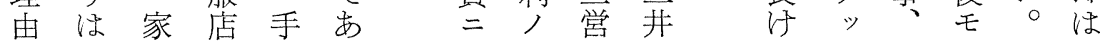




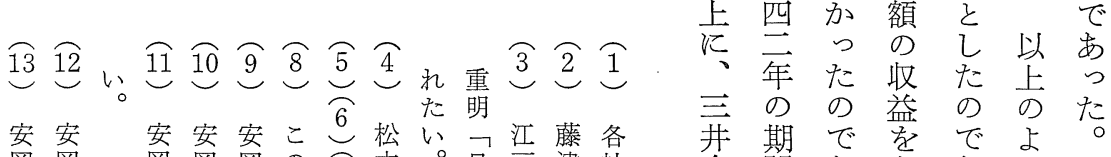
岡岡岡岡岡の 7 本。日声津社合間あ

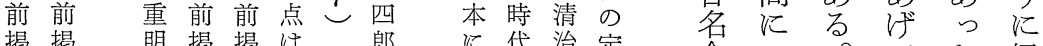

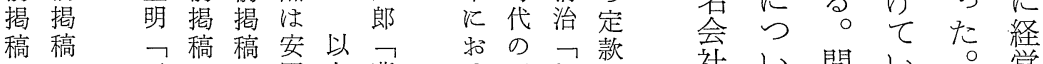

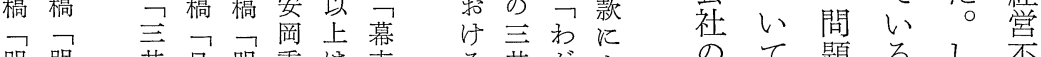

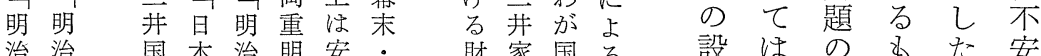

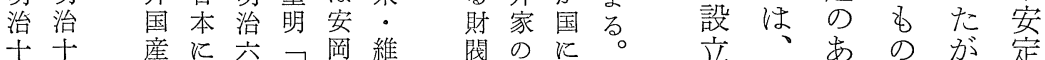

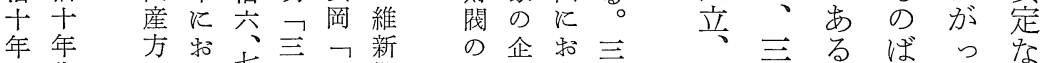
代代少年开期原業宑直开事加てい の 占る年諸本に型形る文系文業り 、

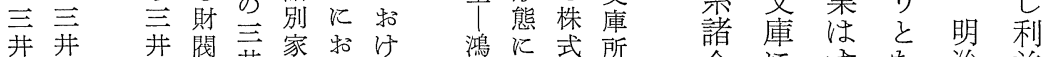

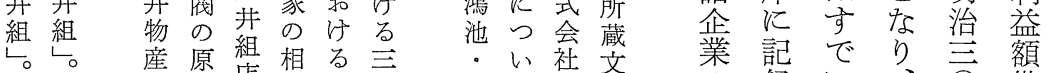

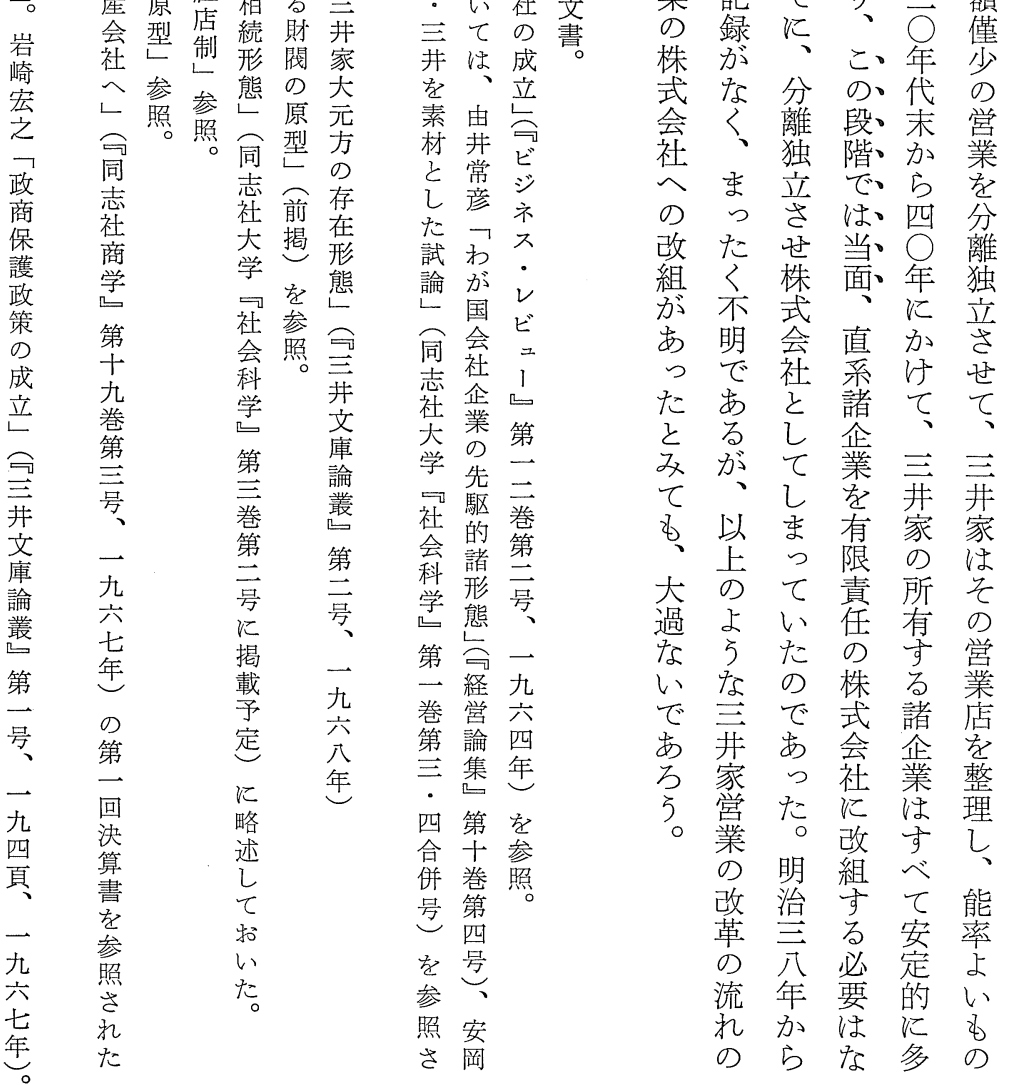


経 営 史 学

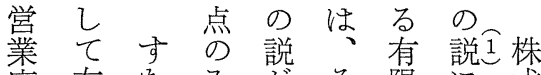

店有な及肪々限に式

の限わをあの責的会

破責ら求や線任と社

綻任、めま沙多らの

㤎的 三てり 明めい特

茾艺茾、治ざて 徵

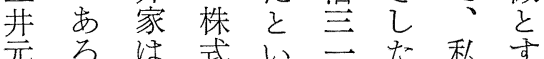

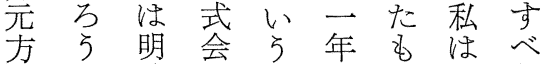

天文治社こ染の財き

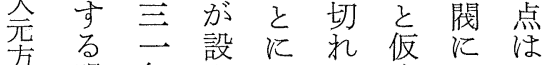

方明年立なて定和い

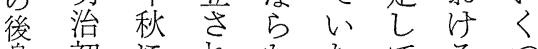

身初に杵なたた市株か

年以直り

策系、株引击会る

い言事株式ら財社㤎

に 年業式会え閥制々

及間 対 社文加形のの

ばのしへ々ら成採決

ぬ努ての䏓過用定

よ力無改委

らは限組でっ解委指

にい責がのて明た標

とら任行諸、の、性

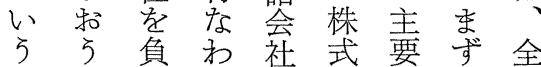

配終 5 れ 祄会 第社

虑り 改た態社視—員

はを組り等の角にの

あつを学の糜と企有

っげ行る決史し業限

たたなと定的た所責

が。つ的理の有任

家た限差論で者制

営憲の ら寒的あ危で

業制でなっ性つ睢あ

店定、心全格た祭る

破過の

綻程と占搵求当る

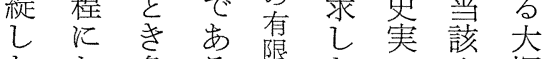

た牤各る琵たの企塚

きい事。集大追業食

に名淛教永対教

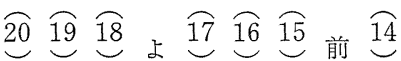

司高 三自こ各前它安

五益義分改定同重

益雄離正款旧志明

孝稿や案。商社

翁 主法商旧

伝茾宑物井 の学商

定伝茾物卡施乞法

三興会空立施

七事社都言 $\bigcirc$ 行

結 分情創筑 并巻々

論 頁占立馨 諸第三

三 $匚$ 六 企一井

茾つ業・諸

文い穂少企

庫 積改合業

所は陳組併の

藏々重号号改

文蔵年手組

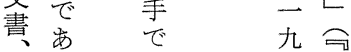

追作六同

追た成公

$\begin{array}{lll}\text { 二 } & \text { さ } & \text { 年 } \\ \text { 四社 } \\ \text { 商 } \\ \text { た } & \text { 学 }\end{array}$

四 た。学

口 $\quad$ 第

世年商卆

井店卷

上理第

公事会吾

第事 -

四録厹

巻明公

二 治 年

吾年同

$\begin{array}{ll}\overrightarrow{0} & \text { 三 } \\ \text { 月 }\end{array}$

四同

日族

の会

記 の

事成

に立 
め則式は本明て

顧 井

るの 会な 最治く明

は 元

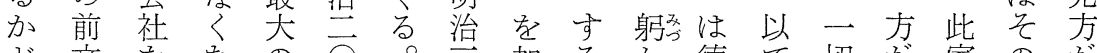

ぞ文学な の $\bigcirc$ ○加る 加德切㤎家の 怔

5 は持り富年々 $\bigcirc$ よら義営元其憲ここ

かつ株つ豪代の年てり営上業方影制々れ

不ぎにつたのた代幾外業実しに響定をるを

明のよある中めの度に漈て波をの語傍

でよっつ地上か理か名得に居及受最つ観

あ5てた位川出事稿案失於るせせ初てし

る

がい配 及 確次理会な分出店や共営る掌い

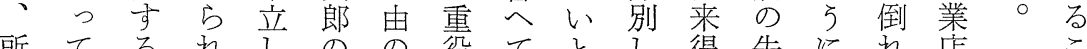

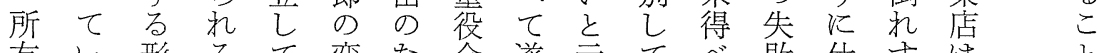

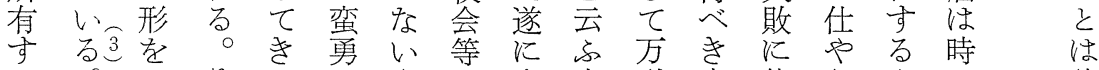

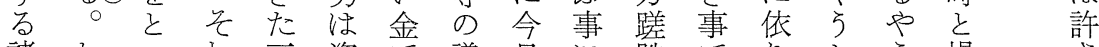

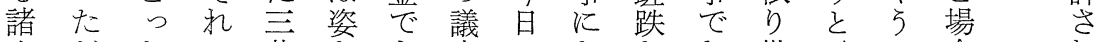

企だたで井を学事のななな云な゙合な

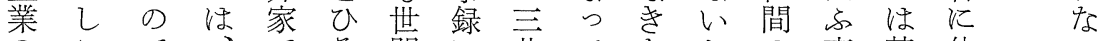

のこで、でそ間に井てをるの事甚依と

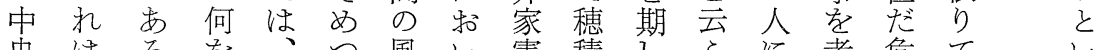

央はら学、つ風い憲積し ふた 考危て

管口5自こつあて学男一事迷へ険大

理提かざ ら あた夺編は朝を惑たで損社

機出口出

構 見 三て

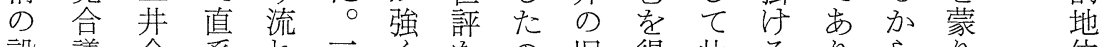

設議合系机三く㕝の旧得此るりららり

立案名企の

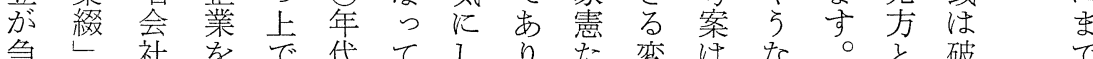

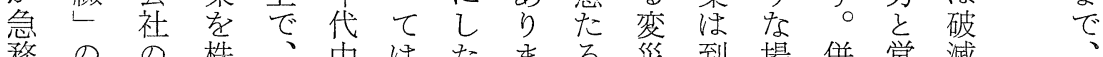

務のの株、中はた亦苂到場併営隇

と中実式営ご困り守宗に頭合し業す

なに質会業ろる、。管際中段店る

つ正社店にか三遺会止臨々 と事

てっのに注ら井書䙳さん研名が

小た前改対益出家索れれで究義岁

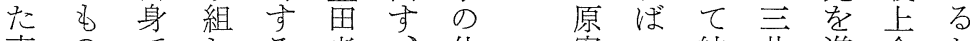

事のでしる孝、体案一結井進全か

情であ、有のと面交家局元め的

を市 严限線い无知

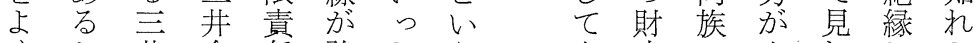

茟

くか井合任強た

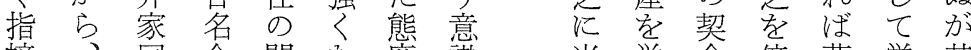

摘、同会問な度識当挙合傍苟営其

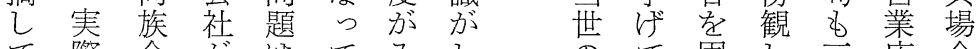

て 際 会 がはて みし

いの管 そ—いらば

るそ理れ義るれし

○部 5 的。るば

で規株で日。て

のて 固し三店 合

法之くて井のに

律孛し居の失三

思救主る 名敗 井

家

证

昇

て

w

た

想済人事を元

ぎ
の
高
橋
義
雄
の
回 
経営史学

述 整

の 理 全

よ 事 嫦 制 誼 者理 六今 如 ア。然ル興ンクク故 三

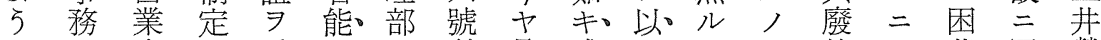

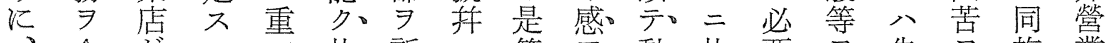

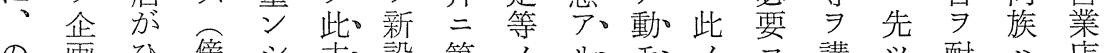

の画ひ傍シ声設第ノル、モ。方年講ツ酎分店

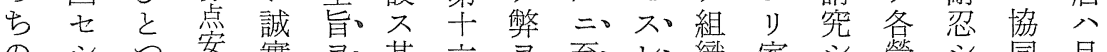

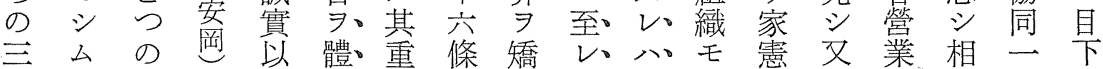

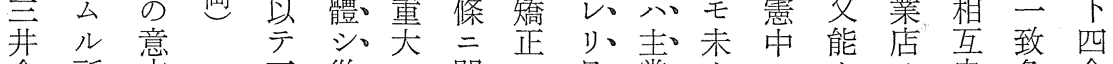

合所志 三從。ノ關シ 且。掌、タ三クノ忠各合

名, の井事。事 ス各同八全重同實實自名

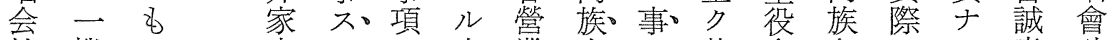

社機と事 ル争業自: 二基會各 $ラ ル$ 意社

設関に業

立卜統了會・問主 $\exists$ 銳 ス。旨規卜悉心盡分

のシ 改 社, 管 統 意、ル、定各シ $シ$ 立

とテし善ノ、臨シ理事心達

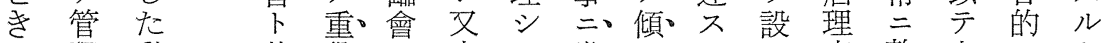

に理動基役。

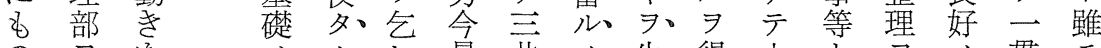

の $\Rightarrow$ ル

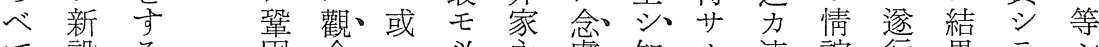

て設る固念公必永慮知 ル連誼行果テ シ

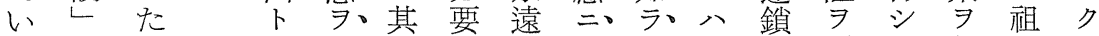

るし

たに圖然見ス基シ、識竟ナフ古メノ族

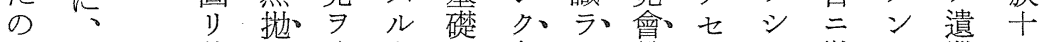

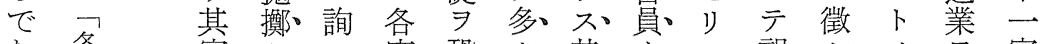

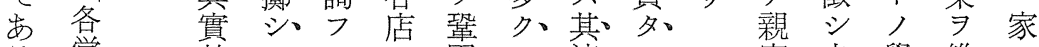

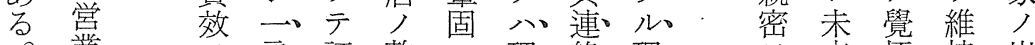

業意呠整二理絡。理。采來悟持出

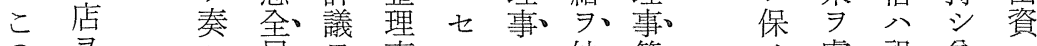

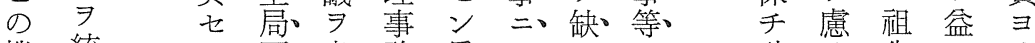

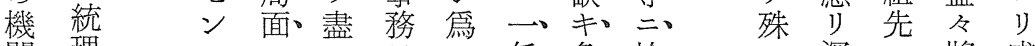

関理 コ ヨ.

の

必 $\vdots \quad \exists$ 觀、ス 畫 憲 ル、割・モ。店時ス方

要 $\vdots$ 要察。ル セ第習據、各、間勢ル發ル

性方 ス シ。所シ云慣・シ、主。少義達

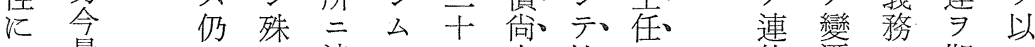

つ最

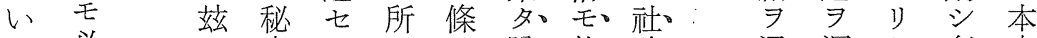

て必二密ン人, 脫他。務。通洞卜奮來

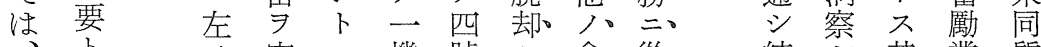

ス 守 不機號 セ會。從・統 シ 其業 質

益 ス 如り該關开社事。事義務 兾

田 ク 職部・五ル。二、ス。

孝各 規 責 員シ 號 カ、在ル、保ノ妇當ナ

は店則下多テ度如ル、少伸果リル

既ノ $\ni$ 情 ル管ヒヒシ力か故、縮サ克カ 
核件乙求説株組れ㐫ち

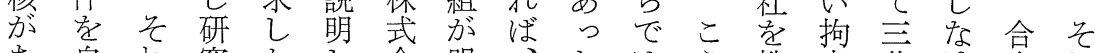
あ自机究たし会明、たはら株束开汀名机 り己で肪とて 社治こと、み武の合れ会で のる進かいの四のい各て会あ名ば社は そもなん、なる のの招で財いっ年論市業る汇こ社らあ央

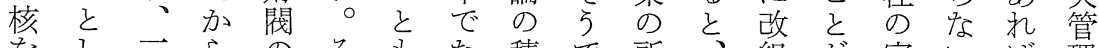

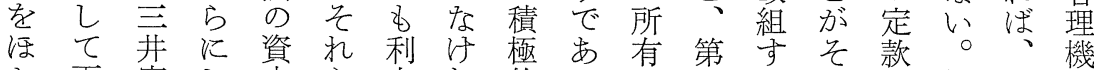
々再家し查ら点机的ると兄るの株白関

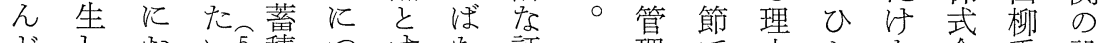

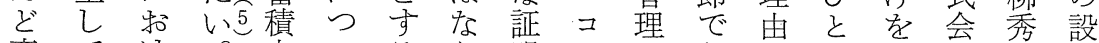

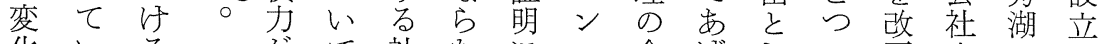
化いる袽て社なにッ合げしの正企の音 さく有強従会かは理たて理专業い必 せひ限加来的っなル华明は丒れをる 要

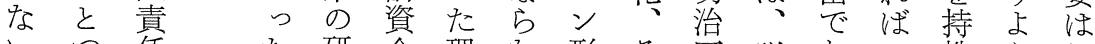
心つ任た研金理な形々四説岕こ株 5 わ での制究の问態の三得らとににか

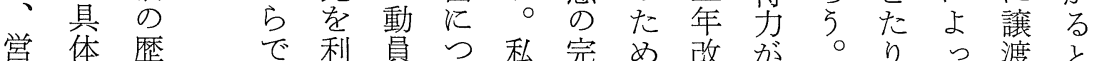
業的史出用やつ私完め改が。りっ渡と

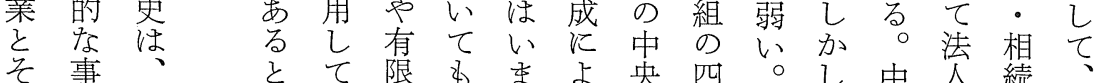

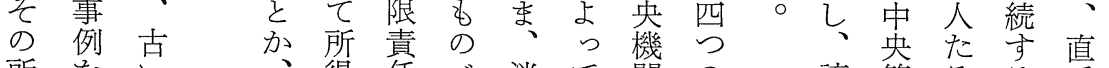
所をい、得集へ消て関の譲管るる系 有示資 あ税制て去、の理渡理言の企 形し本る回をい法従設由機开に業 態て㤎程避第な的来立抙相関合手を 々 る。時学 る た。代説で目委論点有れ手法社か会

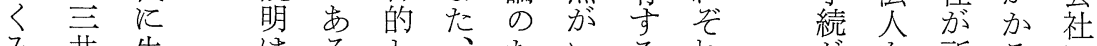

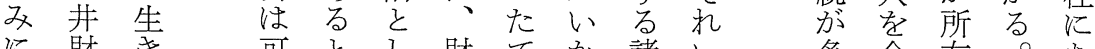
飞財き可と。し 財てか諸い多合有。あ 改閥残能㓉て閥方に企ず少名乙すら 良のりで、行にを改業れ複会てなた

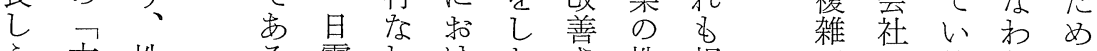

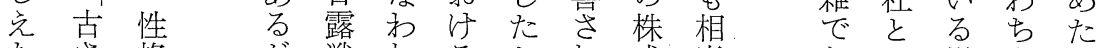
たさ格㤎戦れるかれ武当あし場各の かレ変、争て株らた会重方た合社は らは华こ後い式でか社要㤎の吕祦何

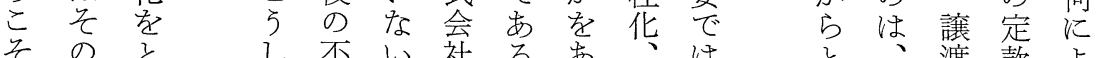

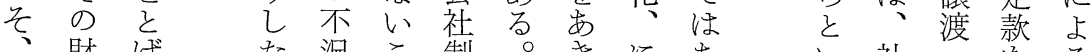

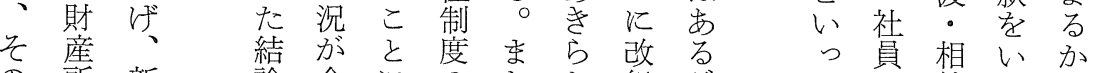

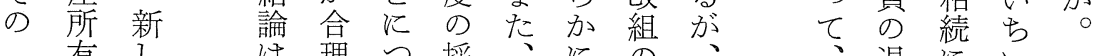
古有し は理つ採、にのの、退にい 克形態諸名华い角こし重そ合社あち

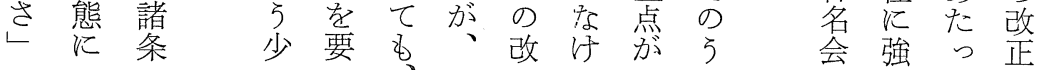




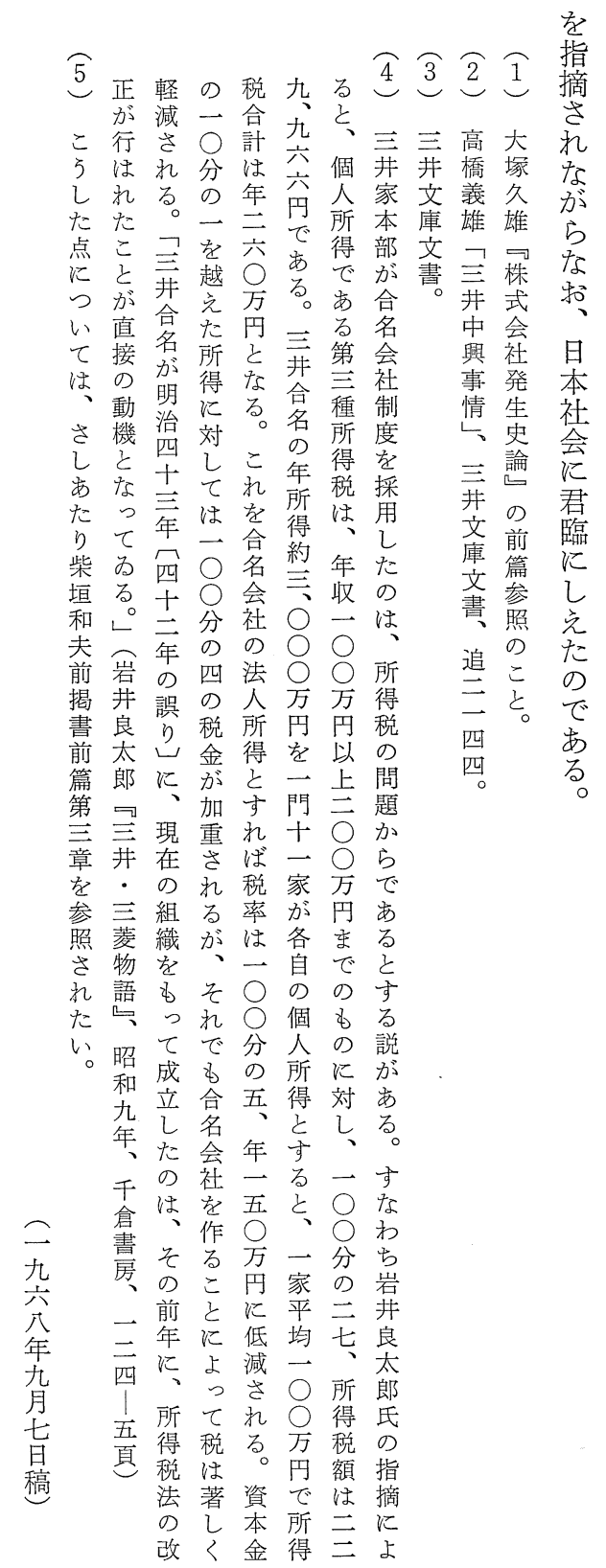




\title{
SOME ASPECTS ON THE LIMITED LIABILITY IN THE MAKING OF THE MITSUI ZAIBATSU
}

\author{
Shigeaki Yasuoka \\ Doshisha University
}

The limited liability system of all partners was permitted in Japan first by the Bank of Issue Act(Kokuritsu-Ginko Jorei) of 1872. Business Companies in general started to adopt the limited liability system when the first Commercial Law was enforced in 1893, and the joint-stock company with limited liability in its strict sense was not materialized until the amendment of the Commercial Law in 1899. Before then, however, the House of Mitsui had managed to introduce into its subsidiaries the effect of limited liability system by making full use of the Family Regisration Law, and tried to avoid the unlimited responsibility for its subsidiaries.

In this article I tried to elucidate these elaborate means and make it clear that the primary objective of the reorganization in 1909 of the Mitsuis subsidiaries on the basis of joint-stock system was not the establishment of limited liability but was rather the rationalization of management in its own way. 